\title{
A MENTÁLIS EGÉSZSÉG KONTINUUM SKÁLA RÖVID VÁLTOZATÁNAK HAZAI VALIDÁCIÓJA
}

\section{REINHARDT MELINDA ${ }^{1,2}$ - HORVÁTH ZSOLT ${ }^{1,3}$ - TÓTH LÁSZLÓ ${ }^{4}$ - KÖKÖNYEI GYÖNGYI ${ }^{1,5,6}$}

\author{
${ }^{1}$ Eötvös Loránd Tudományegyetem, Pszichológiai Intézet \\ ${ }^{2}$ Zuglói Egészségügyi Szolgálat, Gyermek- és Serdülốpszichiátria \\ ${ }^{3}$ ELTE PPK Pszichológiai Doktori Iskola \\ ${ }^{4}$ Testnevelési Egyetem, Gazdaság- és Társadalomtudományi Intézet, Pszichológia \\ és Sportpszichológia Tanszék \\ ${ }^{5}$ SE-NAP 2 Genetikai Agyi Képalkotó Migrén Kutatócsoport, MTA, SE \\ ${ }^{6}$ Semmelweis Egyetem, Gyógyszerhatástani Intézet \\ E-mail: reinhardt.melinda@ppk.elte.hu
}

Benyújtva: 2020. február 18. - Elfogadva: 2020. május 27.

Háttér és célkitűzések: A Mentális Egészség Két-kontinuum Modellje a mentális egészség pozití összetevôit, a szubjektív jóllét komponenseit összegzi. Vizsgálatunkban a modell alapján létrehozott Mentális Egészség Kontinuum Skála rövid változatának (rövid MEKS) pszichometriai mutatóit és faktorszerkezetét teszteltük hazai felnôtt egyetemista mintán.

Módszer: 552 egyetemista $(71,5 \%$ nô, átlagéletkor $=22,09$ év, szórás $=3,66)$ vett részt a keresztmetszeti elrendezésü vizsgálatban, akiket a következô kérdôivek kitöltésére kértünk: Mentális Egészség Kontinuum Skála - rövid változat; Majdnem Tökéletes Skála - rövid változat; Depresszió, Szorongás és Stressz Kérdöiv - rövid változat (DASS-21); Kognitív Érzelem Reguláció Kérdöív - rövid változat és Big Five Személyiségleltár-2 (BFI-2).

Eredmények: A Mentális Egészség Kontinuum Skála rövid változatának a tételek kereszttöltéseit is megengedô (Exploratory Structural Equation Modeling, ESEM) bifaktoros szerkezetét erösítettük meg: a globális szubjektív jóllét faktor erốs jelenléte mellett az eredeti szerzố, Corey L. M. Keyes által leírt három specifikus (érzelmi, pszichológiai és társas) jóllét faktor is megerösitést nyert. A bifaktoros ESEM modell nemi invarianciáját is sikerült igazolnunk. A méröeszköz megbizhatósági eredményei kiválóak $(\omega=0,79-0,92$ között), ahogyan validitása is bizonyítást nyert: az elvártaknak megfelelöen a pozitív mentális egészség mutatók (teljes rövid MEKS és alskálái) a depresszív, a szorongásos és a stressz tünetekkel, valamint az önkritikus, maladaptív perfekcionizmussal fordított irányú együtt járást mutatnak, míg az adaptív kognitív érzelemregulációs stratégiákkal és az alkalmazkodást segitố személyiségvonásokkal (barátságosság, lelkiismeretesség, érzelmi stabilitás, extraverzió) pozitív kapcsolatban állnak.

Következtetések: Eredményeink szerint egy valid, a szubjektív jóllét szintet globálisan és annak egyes területeit is megbizhatóan mérố önkitöltốs kérdốivet tudtunk bevezetni a magyar tesztállományba.

Kulcsszavak: szubjektív jóllét, Mentális Egészség Kontinuum Skála rövid változat, validáció, faktorszerkezet 


\section{BEVEZETÉS}

A mentális egészséget leíró kurrens elméletek kivétel nélkül amellett foglalnak állást, hogy az jóval többet jelent a mentális betegségtünetek egyszerú hiányánál. Részben ebbôl a szemléletból következik, hogy a mentális egészség különbözó aspektusainak feltárására helyezik a hangsúlyt (Wang, Zhang és Wang, 2011).

A mentális egészség vizsgálata ugyan nem új keletú fókuszpont a lélektanban, hiszen a mentális betegségek, tünetek fogalmi tisztázása mindig is magában foglalta azt, hogy mi számít lelki értelemben „normatívnak”, ilyen értelemben egészségesnek. Mégis, a mentális egészség a maga szó szerinti, tehát pozitív értelmében sokáig nem jelent meg a pszichiátriában és a pszichológiában, illetve általában a mentális betegségtünetek hiányát értették alatta. Bár az 1970-es évektôl megindultak a jelenség konceptualizálására és felmérési lehetôségeinek kidolgozására tett elsô kísérletek (Vaillant, 2003), a mentális egészség empirikus igényú megközelítése csak késôbb, a pozitív pszichológia megjelenésétôl indult dinamikus fejlődésnek. Az ezredfordulón körvonalazódó pozitív pszichológia ugyanis az új irányzat célját annak vizsgálatában határozta meg, hogy mely humán képességek segítik az egyént és a társadalmat abban, hogy fejlôdjön, sốt virágozzon (Seligman és Csikszentmihalyi, 2000). Bevezették a pozitív mentális egészség fogalmát, amely egy olyan definiálható és mérhetô állapot, amely a testi, a szubjektív és a mindennapi kiváló múködés kombinációjaként határozható meg (Seligman, 2008). Érdemes kiemelnünk azt is, hogy a Csíkszentmihályi Mihály által leírt flow jelenség pozitív hatással bír a szubjektív jóllét és így a mentális egészég alakulására. Az autotelikus személyiséggel jellemezhetô, azaz az átlagosnál több flow-élményt átélő személyek például magasabb pszichológiai jóllétrôl számoltak be egy longitudinális utánkövetés során (Csikszentmihalyi és Csikszentmihalyi, 1988). Hazánkban a szubjektív jóllét (pl. Oláh, 2012; Oláh és Kapitány-Fövény, 2012) és tágabb keretben a személyiség pozitív erôforrásainak (pl. Kiss, 2015) kutatása és nemzetközi teoretikus modelljeinek bevezetése fơként Oláh Attila és Kiss Enikô kutatócsoportjainak munkásságához füződik.

A 21. század elsô évtizedében több olyan komplex modell is megjelent, amelyek a pozitív lelki egészség konstruktumát kívánták operacionalizálni, egyben annak a mentális betegségtünetekkel való viszonyát tisztázni (pl. Ryff és Singer, 2002: a pszichológiai jóllét eudaimonikus megközelítése; Seligman, 2002: az autentikus életöröm elmélete; Peterson és Seligman, 2004: a karaktererôsségek rendszere; Fredrickson és Losada, 2005: az ún. broaden-and-build model a pozitív emóciók adaptivitásáról; Suldo és Shaffer, 2008: a mentális egészség kétfaktoros modellje; Durayappah, 2011: a szubjektív jóllét 3P modellje; Seligman, 2011: a virágzás [flourishing] elmélete). Ezek közül a modellek közül összetettségében és elméleti megalapozottságában, valamint empirikus teszteltségében is kiemelkedik a Corey L. M. Keyes által megalkotott Mentális Egészség Két-kontinuum Modell (Two Continua Model of Mental Health vagy Dual-Continua Model of Mental Health; Keyes, 2002a, 2002b). 


\section{A Mentális Egészség Két-kontinuum Modellje}

A Mentális Egészség Két-kontinuum Modellje (Keyes, 2002a; Keyes és Haidt, 2002; Keyes és Waterman, 2003) a mentális egészséget és a mentális betegségtüneteket nem egymás ellentétes tartalmú jelenségeinek és nem egy képzeletbeli egyenes két végpontján elhelyezkedô állapotoknak tekinti, hanem két külön kontinuummal - mentális egészség kontinuum és mentális betegség kontinuum - és az azokból felépülô kategóriákkal számol, amikor a lelki egészségrôl beszél.

A modell másik újdonsága, hogy a mentális egészséget - a mentális betegségkategóriák analógiájára - egy olyan „szindrómaként” (syndrome) írja le, amely „tünetek” (symptoms) meghatározott idôtartamon át jelen lévô jellegzetes konstellációjából épül fel. A „tünetek” a szubjektív jóllét egyes aspektusait jelentik, maga a „tünetegyüttes” pedig magas fokú kognitív és társas múködési szinttel jár együtt (Keyes, 2013).

Keyes az 1990-es évek közepétól kezdte el szisztematikusan tanulmányozni a boldogságra és a lelki jóllétre vonatkozó filozófiai, etikai és lélektani munkákat az antikvitástól napjainkig. Integratív és multidimenzionális jóllét modellje ezzel a szubjektív jóllét kutatások mindkét irányvonalát egyesíteni tudta, hiszen a pozitív mentális egészséget mind a hedonikus (érzelmi jóllét), mind az eudaimonikus (pszichológiai és szociális) jóllét aspektusaiban leírja (Keyes és Waterman, 2003, 1. ábra). Fontos hangsúlyozni, hogy Keyes (2002a) a szubjektív jóllét társas vonatkozásait is beemeli modelljébe, rámutatva ezzel, hogy optimális funkcionálás csakis a szociális jóllét aspektusokkal együtt lehetséges.

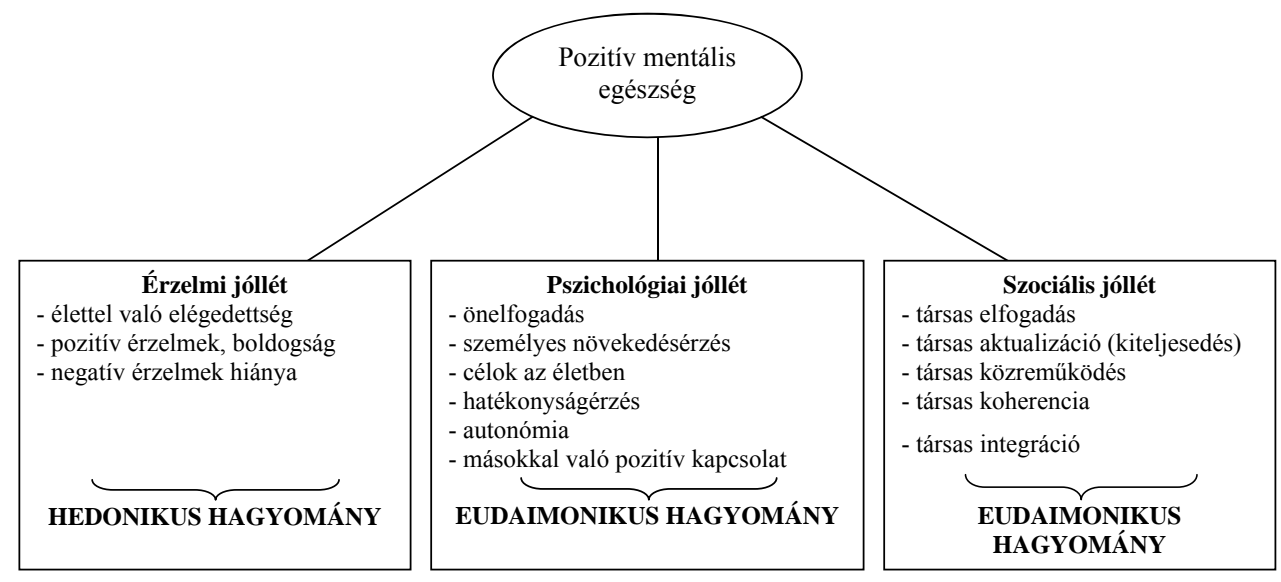

1. ábra. A pozitív mentális egészség összetevői (Keyes és Waterman, 2003, 482-484. alapján)

Az érzelmi jóllét a pozitív érzelmek (pl. jó hangulat, öröm) jelenlétét, a negatívak (pl. reménytelenség) hiányát, valamint a saját élet minôségének érzelmi alapú becslését (élettel való elégedettség) összegzi (Diener, 1984).

A pszichológiai jóllét Carol Ryff pozitív funkcionálás modelljéhez (Ryff, 1989) nyúl vissza, s az abban azonosított hat dimenziót veszi át, melyek a következôk (magyarul részletesen ld. Reinhardt, 2014): 
1. Önelfogadás (self-acceptance): a saját szelf felé irányuló pozitív attitûdök és a saját múlttal kapcsolatos pozitív érzelmek.

2. Másokkal való pozitív kapcsolatok (positive relations with others): meleg, kielégító, megbízható kötelékek, intimitásra, ragaszkodásra és empátiára való képesség, mások jólétével való törôdés.

3. Autonómia (autonomy): a szabad akarat és függetlenség érzete, a társas nyomásnak való ellenállás képessége; intrinzik motivált cselekedetek, az én személyes standardok alapján való értékelése.

4. A környezettel kapcsolatos hatékonyságérzés (environmental mastery): a környezet kezelésével kapcsolatos hatékonyság- és kompetenciaérzés, a felmerülô lehetôségek hatékony kiaknázása és az arra való képesség, hogy a személyes szükségleteinknek és értékeinknek megfelelô környezetet válasszunk vagy alakítsunk ki.

5. Célok (purpose in life): célok megléte és kialakítási képessége, annak az érzése, hogy képesek vagyunk irányítani az életünket, és jelenbeli, illetve múltbeli létezésünknek értelme van.

6. Személyes növekedés (personal growth): a folyamatos fejlődésre való képesség érzete, nyitottság az új tapasztalatokra, képesség a lehetôségek kibontakoztatására, az önismeret és az énhatékonyság növekedésének átélése.

A szubjektív jóllét a keyesi felfogásban (Keyes, 1998) az életterületek „közfeladatait” is magában foglalja. A társas jóllét ebben a keretben annak becslését jelenti, hogy valakinek milyenek a társas körülményei és hogyan múködik közösségi szinteken. A szociálisan integrált személyt az alábbiak jellemzik (magyarul részletesen ld. Reinhardt, 2014):

1. Társas integráció (social integration): az egészséges személyek úgy érzik, hogy a társadalom szerves részeként élnek közösségükben, különbözó csoportokkal (pl. család, iskolai, munkahelyi, baráti) egy közösséget alkotnak, képesek a kollektív részvétre.

2. Társas elfogadás (social acceptance): másokba vetett bizalom, abban való hit, hogy a többi ember képes arra, hogy kedves, szorgalmas és megbízható legyen.

3. Társas részvétel/társas közremúködés (social contribution): az abban való hit, hogy valaki értékes és aktív tagja a társadalomnak. Keyes (1998) hasonló konstruktumnak tartja az énhatékonysághoz és a felelôsségvállaláshoz.

4. Társas aktualizáció, kiteljesedés (social actualization): a társas, társadalmi lehetôségek kibontakoztatásának képessége, valamint az abban való hit, hogy a közösségek fejlődni tudnak.

5. Társas koherencia (social coherence): képesség és igény annak megértésére, hogy mi történik a minket körülvevô társas térben, és az hogyan szervezôdik és múködik. Keyes (2005a) a mentális egészség és a mentális betegség elkülönülő, bár kapcsolódó dimenzióiból egy olyan modellt is felépített, amely a pszichoszociális múködésmód teljes spektrumát árnyalt kategóriákban ragadja meg. A mentális egészség kontinuumát a - tôle részben független - mentális betegség kontinuum jelenléte vagy hiánya befolyásolja, ami fordítva is érvényes (Keyes, Shmotkin és Ryff, 2002). A két dimenziót ha egymásra merólegesen helyezzük el, a mentális egészség három fokozata és a mentális betegség két állapota rajzolódik ki (2. ábra). 


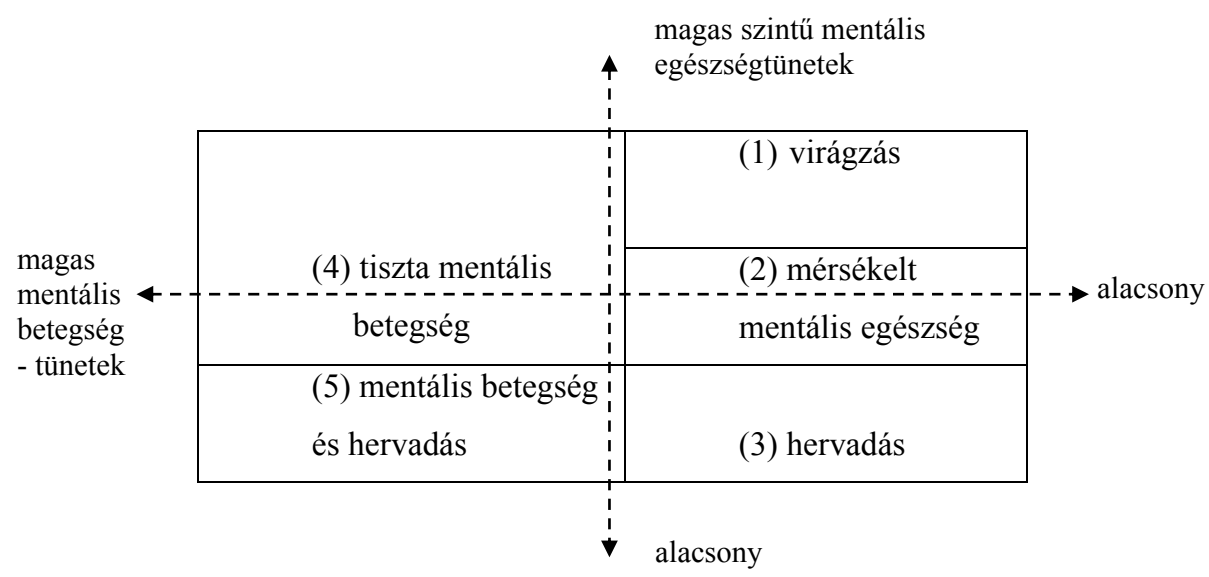

2. ábra. A teljes mentális egészség modell és annak diagnosztikai kategóriái Keyes (2002b, 302) alapján

A legkiválóbb pszichés múködésmóddal jellemezhetô személyek az érzelmi, a pszichológiai, és a társas jóllét magas szintjét élik meg, miközben mentesek a mentális betegségtünetektôl. Ennek az optimális állapotnak, a teljes mentális egészségnek (complete mental health) a leírására Keyes (2002a) a (1) virágzás (flourishing) fogalmát vezette be. Ezzel ellentétben az alacsony emocionális, pszichológiai és szociális jólléttel rendelkezôk hiányos mentális egészséggel jellemezhetôk, ôk egy másik keyesi metaforával élve a (3) hervadók (languishing). A virágzás és a hervadás között a (2) mérsékelt mentális egészség (moderate mental health) állapota található. Akik ebbe a kategóriába sorolhatók, szintén mentesek a mentális betegségpanaszoktól, azonban mindhárom jóllétterületen közepes, átlagos értékeket érnek el.

Előfordulhat, hogy jelen lévố mentális betegségtünetek mellett a szubjektív jóllét egyes szintjei átlagos vagy magas értékeket vesznek fel. Ebben az esetben (4) tiszta mentális betegségrôl (pure mental illness) beszélhetünk. Végül lehetséges, hogy a (5) mentális betegség tüneteihez a hervadás elemei társulnak (mental illness and languishing) (Keyes, 2005a): az ebbe a csoportba tartozók nem tudnak a hiányzó érzelmi, pszichológiai és társas jóllét forrásaikból védőfaktorokat mozgósítani lelki problémáik leküzdéséhez. Mivel ez a csoport bír a legrosszabb prognózissal, óket Keyes és Lopez (2002) metaforikusan tehetetlenül vergôdooknek (floundering) nevezték el.

A fenti mentális állapotok a pszichoszociális funkcionálás különbözô minôségeit képviselik, melyekben a lelki egészséget és betegséget együttesen becsülik meg. Mindezt a 3. ábra összegzi, ahol balról jobbra haladva az egyre magasabb szintú pszichoszociális múködésmód állapotai jelennek meg.

\begin{tabular}{|c|c|c|c|c|c|c|}
\hline $\begin{array}{c}\text { Pszichés betegség } \\
\text { és hervadás }\end{array}$ & $<$ & $\begin{array}{l}\text { Pszichés betegség } \\
\text { önmagában }\end{array}$ & $\approx$ & $\begin{array}{c}\text { Hervadás < } \\
\text { önmagában }\end{array}$ & $\begin{array}{l}\text { Mérsékelt < } \\
\text { mentális egészség }\end{array}$ & $\begin{array}{l}\text { Teljes } \\
\text { mentális egészség }\end{array}$ \\
\hline
\end{tabular}

3. ábra. A pszichoszociális múködésmód becslése a Mentális Egészség Két-kontinuum Modellje szerint (Keyes, 2005a, 541) 


\section{A Mentális Egészség Kontinuum Skála rövid változatának bemutatása és pszichometriai jellemzôi}

A Mentális Egészség Két-kontinuum Modelljére alapozva a mentális egészség átfogó, valamint az azt felépító három szubjektív jóllét terület - az érzelmi, a pszichológiai és a szociális jóllét - kérdôíves felmérésére alakította ki Keyes (2002a) a Mentális Egészség Kontinuum Skálát. Folyamatos empirikus munkát követôen, 2008-ban egy 40 tételes változatból 14 tételesre rövidített skálát adott közre (Keyes, Wissing, Potgieter, Temane, Kruger és Van Rooy, 2008), amelyet Mental Health Continuum - Short Formnak (MHC-SF) nevezett el. Ezzel párhuzamosan a méróeszköz serdülô változata is elkészült (Adolescent Mental Health Continuum - Short Form, A-MHC-SF; Keyes, 2006, 2009a). Az angol nyelvú kérdőívet számos nyelvre lefordították (pl. kanadai franciára, koreaira, kínaira, japánra, hollandra, norvégra, svédre, finnre, magyarra).

Az MHC-SF 14 tétele a korábbi, 40 tételes változat legprototipikusabb tételeit ôrizte meg. A kitöltônek arra kell választ adnia, hogy az elmúlt egy hónapban milyen gyakran élte át azt az érzést vagy folyamatot, amelyet az egyes tételek megfogalmaznak. A válaszok egy 5-fokú skálán a „sohá”-tól (0) a „minden nap”-ig (5) terjednek. A kérdôív összességében a válaszadó szubjektív jóllétét globálisan írja le, míg három skálája az egyes jóllétterületeket külön-külön összegzi. Az elsô 3 tétel az érzelmi jóllétet méri fel (pl. 3. tétel: Az elmúlt egy hónapban milyen gyakran érezte azt, hogy: elégedett volt az életével?). A 4-8. tétel a szociális jóllét területét tapogatja le (pl. 7. tétel: Az elmúlt egy hónapban milyen gyakran érezte azt, hogy: az emberek alapvetốn jók?). Az utolsó hat tétel (9-14.) pedig a pszichológiai jóllétet összegzi (pl. 12. tétel: Az elmúlt egy hónapban milyen gyakran érezte azt, hogy: a személyisége legtöbb részét szereti, elfogadta?). Fordított tétel nincs, a válaszok öszszegzése két módon történhet. (I) Meghatározható a teljes kérdőíven és az egyes skálákon elért összpontszám, elôbbi 0 és 70 pont közé eshet. A magasabb pontszám minden esetben jobb jóllétértéket jelez. (II) Lehetôség nyílik egy kategoriális besorolásra is, amikor a mentális egészségtünetek megélési gyakoriságát vesszük alapul. A „virágzók” az érzelmi jóllét 3 tünete közül legalább egyet majdnem minden nap vagy minden nap átélnek, valamint a pszichológiai és a társas jóllét 11 tünetéból legalább hatot szintén minden nap vagy majdnem minden nap megtapasztalnak. Ezzel ellentétben a „hervadók" az érzelmi jóllét 3 tünete közül az egyiket az elmúlt egy hónapban soha vagy csak egyszer-kétszer tapasztalták, ahogyan a pszichológiai és a társas jóllét 11 szimptómájából minimum hatot soha vagy csak egyszer-kétszer éltek át. A mérsékelt mentális egészség kategóriájába azokat soroljuk, akik nem tartoznak sem a virágzókhoz, sem a hervadókhoz (Keyes és mtsai, 2008).

Az MHC-SF tesztelése során rendre kiváló pszichometriai eredményeket hozott (pl. Keyes és Waterman, 2003; Keyes és mtsai, 2008; Keyes és Michalec, 2010; Westerhof és Keyes, 2010; Yin, He és Fu, 2013). Számos nemzeti mintán a kérdôív megbízhatónak és validnak bizonyult. A Cronbach-alfa-értékek minden esetben 0,80 felettiek voltak, ez alól kivételt csak az egyiptomi változat (Salama-Younes, 2011) jelentett. A teszt-reteszt reliabilitás 3 hónap után 0,68, 9 hónap után pedig 0,65 volt (Lamers, Westerhof, Bohlmeijer, Klooster és Keyes, 2011). A skála továbbá megfelelô diszkrimináns (a mentális betegségtünetekkel szignifikáns negatív korrelációban áll) és konvergens validitással bír (az emocionális jóllét például a pozitív affektivitással mutat szoros kap- 
csolatot, míg a pszichés jóllét az önbecsülést felmérô skálákkal) (pl. Lamers és mtsai, 2011). A három skála egymással közepesen vagy erôsen korrelál. Lamers, Westerhof, Kovács és Bohlmeijer (2012) vizsgálatában az érzelmi és a pszichés jóllét között például 0,58, az érzelmi és a társas jóllét között 0,50 , valamint a pszichológiai és a társas jóllét között 0,70 volt a korreláció.

Az elmúlt évtizedben számos tanulmány tesztelte az MHC-SF faktorstruktúráját is. Az egy- és a kétdimenziós struktúrát a kutatások elvetették (kivéve Machado és Bandeira, 2015). Néhány tanulmány az eredeti háromfaktoros struktúrát (érzelmi, pszichés és társas jóllét) erôsítette meg mind felnôtt (pl. Robitschek és Keyes, 2009; Lamers és mtsai, 2011, Joshanloo, 2017), mind serdülố mintán (pl. Lim, 2014; Guo, Tomson, Guo, Li, Keller és Söderqvist, 2015; Orpana, Vachon, Dykxhoorn és Jayaraman, 2017). Más kutatások a bifaktoros megoldást támogatták (pl. De Bruin és Du Plessis, 2015; Lamborn, Cramer és Riderby, 2018; Rogoza, Truong Thi, Różycka-Tran, Piotrowski és Żemojtel-Piotrowska, 2018), amely egy általános szubjektív jóllét faktor és egyidejüleg a három jóllét alfaktor (érzelmi, pszichológiai és társas) jelenlétét erôsíti meg. Megint mások mind a háromfaktoros, mind a bifaktoros szervezódést jól illeszkedônek írták le (pl. Doré, O’Loughlin, Sabiston és Fournier, 2017; Peña Contreras és mtsai, 2017). A bifaktormodell megerôsítése azért is különösen fontos, mert azt jelzi, hogy mind az egyes well-being faktorok (emocionális, pszichológiai és szociális), mind ezek kombinációja, azaz a globális well-being érvényes interpretációval bírnak. A kutatások továbbá szinte kivétel nélkül a mérôeszköz nem (pl. Petrillo, Capone, Caso és Keyes, 2014; Sampaio de Carvalho, Salgado Pereira, Marques Pinto és Maroco, 2016), életkor (pl. Lupano Perugini, De la Iglesia, Solano és Keyes, 2017; Rogoza és mtsai, 2018) és kulturális csoportok (pl. Joshanloo, Wissing, Khumalo és Lamers, 2013) szerinti invarianciáját is rögzítették. Ezek az eredmények azt jelzik, hogy a kérdőívet a különbözô életkorú, nemú és kultúrához tartozó személyek ugyanúgy értelmezik. Reprezentatív magyar serdülô mintában is megerôsítést nyert a kérdôív bifaktoros struktúrája, valamint nemi és életkori invarianciája (Reinhardt, Horváth, Morgan és Kökönyei, 2020).

\section{A Mentális Egészség Kontinuum Skála összefüggései a mentális és testi betegség tünetekkel és bizonyos személyiségvonásokkal}

A Mentális Egészség Kontinuum Skálával végzett alapvizsgálat (Keyes, 2002a) szerint a lelki egészség dimenziói (a szubjektív jóllét mutatók) egyértelmúen elkülöníthetôk a lelki betegség tüneteitôl. Ugyanakkor a vizsgálat arra is rámutatott, hogy a hervadók 28\%-a major depresszióban szenvedett a felmérést megelőzó évben. Keyes egy másik, 2005-ös publikációjának eredményei szerint a krónikus egészségügyi problémák száma azok között az idôs amerikaiak között volt a legmagasabb, akiknél a több depresszív tünet hervadással kombinálódott. A legkevesebb pszichés és krónikus testi betegségtünettel a virágzó 65 év felettiek bírtak (Keyes, 2005b). Egy másik vizsgálatban a virágzó személyek nagyobb valószínúséggel alkalmaztak adaptív érzelemszabályozó stratégiákat, míg a hervadók inkább maladaptív emócióregulációs módokat (Basson és Rothman, 2018). Az egyes szubjektív jóllét területek és a globális jóllét mutató az eddigi vizsgálatok szerint a depresszív és a szorongásos tünetekkel fordított, közepes 
erôsségú kapcsolatban állnak (pl. Luijten, Kuppens, Van de Bongardt és Nieboer, 2019). A vizsgálatok azt is egyértelmúen megerôsítik, hogy más személyiségvonások köthetốk a pozitív mentális egészséghez, mint a mentális betegségtünetekhez. Az extraverzió, a barátságosság és a lelkiismeretesség - a demográfiai változók kontrollja mellett is - rendre a mentális egészség pozitív tartományát jelzik előre, míg az érzelmi instabilitás (neuroticizmus) a fennálló pszichopatológiai tüneteket (pl. Joshanloo és Nosratabadi, 2009; Lamers és mtsai, 2012).

\section{Jelen vizsgálat célkitúzései}

Vizsgálatunk elsôdleges célja magyar felnôtt mintában validálni az MHC-SF magyar változatát, a Mentális Egészség Kontinuum Skála rövid változatát (MEKS). A skála reliabilitás, valamint konvergens és diszkrimináns validitás mutatóinak elemzésén túl ennek a folyamatnak a skála megerôsítô faktorelemzése is a része. A faktorelemzés során versengố modellek (egy-, két-, három-, valamint bifaktoros megoldás) közül választjuk ki a pszichometriailag legjobban illeszkedô faktorszerkezetet. Vizsgáljuk továbbá a MEKS invarianciáját a nem tekintetében, annak érdekében, hogy ellenôrizzük, a magyar változat egyes tételeit az eltérô nemú felnôtt személyek hasonlóképpen értelmezik-e. Végül célul tûztük ki a kategoriális felosztás három csoportjának - virágzók, mérsékelt mentális egészséggel bírók, hervadók - összehasonlítását az adaptív és a maladaptív kognitív érzelemszabályozó stratégiák és bizonyos személyiségvonások (Big Five és perfekcionizmus) tekintetében. Hipotézisünk szerint a legkiválóbb jóllétszinttel jellemezhetô virágzó személyek írhatók le a legadaptívabb érzelemregulációs stratégiákkal és személyiségjellemzókkel.

\section{MÓDSZER}

\section{Minta}

A mintát 552 egyetemista felnôtt alkotta. Átlagéletkoruk 22,09 év (szórás: 3,66, terjedelem = 18-48 év $), 71,4 \%$-uk $(\mathrm{N}=394)$ nô, 28,6\%-uk $(\mathrm{N}=158)$ férfi volt. A férfiak és a nốk sem életkori átlagukban, sem az elvégzett szemeszterek átlagos számában, sem lakóhelyük típusának eloszlásában nem különböztek egymástól, ahogyan szubjektíven megítélt életszínvonaluk és fizikai egészségi állapotuk sem mutatott eltérést. A mért demográfiai változók tekintetében egyedül a családi állapot eloszlásában jelent meg nemi különbség: kevesebb férfi él párkapcsolatban, mint nô. A minta alapadatait részletesen az 1. táblázat tartalmazza.

\section{Eszközök}

A kérdôívcsomagban a demográfiai kérdések (pl. nem, kor, családi állapot, szak, elvégzett szemeszterek száma, legutóbbi félév tanulmányi átlaga) mellett összesen hat kérdőív szerepelt. Az alábbiakban a validációs folyamat szempontjából fontos öt mérôeszközt mutatjuk be. 
1. táblázat. A minta leíró adatai összesítve és nemi bontásban

\begin{tabular}{|c|c|c|c|c|}
\hline & $\begin{array}{l}\text { Teljes minta } \\
\mathrm{N}=552\end{array}$ & $\begin{array}{l}\text { Férfiak } \\
\mathrm{N}=158\end{array}$ & $\begin{array}{c}\text { Nók } \\
\mathrm{N}=394\end{array}$ & $\begin{array}{c}\text { A két nem } \\
\text { összehasonlítása } \\
\text { (statisztikai próba } \\
\text { értéke) }\end{array}$ \\
\hline $\begin{array}{l}\text { Életkor }(M[S D]) \\
\text { [terjedelem] }\end{array}$ & $\begin{array}{c}\text { 22,09 év }(3,66) \\
{[18-48 \text { év] }}\end{array}$ & $\begin{array}{c}21,91 \text { év }(2,95) \\
{[18-38 \text { év] }}\end{array}$ & $\begin{array}{c}\text { 22,16 év (3,91) } \\
{[18-48 \text { év] }}\end{array}$ & $\begin{array}{c}\mathrm{t}(550)=0,74 \\
\mathrm{p}=0,462\end{array}$ \\
\hline $\begin{array}{l}\text { Elvégzett } \\
\text { szemeszterek }\end{array}$ & $\begin{array}{c}\text { 3,99 félév }(2,52) \\
{[0-16 \text { félév }]}\end{array}$ & \begin{tabular}{|c|}
3,92 félév $(2,80)$ \\
{$[0-16$ félév] }
\end{tabular} & \begin{tabular}{|c|}
4,02 félév $(2,41)$ \\
{$[0-14$ félév $]$}
\end{tabular} & $\begin{array}{c}\mathrm{t}(508)=0,40 \\
\mathrm{p}=0,693\end{array}$ \\
\hline \multicolumn{5}{|l|}{ Lakhely } \\
\hline fốváros & $39,3 \%(\mathrm{~N}=217)$ & $42,4 \%(\mathrm{~N}=67)$ & $38,1 \%(\mathrm{~N}=150)$ & \multirow{3}{*}{$\begin{array}{c}\chi^{2}(2)=2,73 \\
p=0,255\end{array}$} \\
\hline más város & $43,3 \%(\mathrm{~N}=239)$ & $44,3 \%(\mathrm{~N}=70)$ & $42,9 \%(\mathrm{~N}=169)$ & \\
\hline község, falu & $17,4 \%(\mathrm{~N}=96)$ & $13,3 \%(\mathrm{~N}=21)$ & $19,0 \%(\mathrm{~N}=75)$ & \\
\hline \multicolumn{5}{|l|}{ Családi állapot } \\
\hline hajadon/nôtlen & $55,3 \%(\mathrm{~N}=305)$ & $63,9 \%(\mathrm{~N}=101)$ & $51,8 \%(\mathrm{~N}=204)$ & \multirow{2}{*}{$\begin{array}{c}\chi^{2}(1)=6,73 \\
p=0,009\end{array}$} \\
\hline kapcsolatban él & $44,7 \%(\mathrm{~N}=247)$ & $36,1 \%(\mathrm{~N}=57)$ & $48,2 \%(\mathrm{~N}=190)$ & \\
\hline \multicolumn{5}{|c|}{ Szubjektív életszinvonal } \\
\hline $\begin{array}{l}\text { jelentôsen átlag } \\
\text { felett }\end{array}$ & $2,2 \%(\mathrm{~N}=12)$ & $3,2 \%(\mathrm{~N}=5)$ & $1,8 \%(\mathrm{~N}=7)$ & \multirow{5}{*}{$\begin{array}{c}\chi^{2}(4)=9,18 \\
p=0,057\end{array}$} \\
\hline átlag felett & $24,5 \%(\mathrm{~N}=135)$ & $29,7 \%(\mathrm{~N}=47)$ & $22,3 \%(\mathrm{~N}=88)$ & \\
\hline átlagos & $47,8 \%(\mathrm{~N}=264)$ & $38,6 \%(\mathrm{~N}=61)$ & $51,5 \%(\mathrm{~N}=203)$ & \\
\hline átlag alatt & $19,7 \%(\mathrm{~N}=109)$ & $23,4 \%(\mathrm{~N}=37)$ & $18,3 \%(\mathrm{~N}=72)$ & \\
\hline $\begin{array}{l}\text { jelentôsen átlag } \\
\text { alatt }\end{array}$ & $5,8 \%(\mathrm{~N}=32)$ & $5,1 \%(\mathrm{~N}=8)$ & $6,1 \%(\mathrm{~N}=24)$ & \\
\hline \multicolumn{5}{|l|}{ Fizikai egészség } \\
\hline kitûnố & $25,4 \%(\mathrm{~N}=140)$ & $26,6 \%(\mathrm{~N}=42)$ & $24,9 \%(\mathrm{~N}=98)$ & \multirow{4}{*}{$\begin{array}{c}\chi^{2}(3)=5,51 \\
p=0,138\end{array}$} \\
\hline jó & $54,5 \%(\mathrm{~N}=301)$ & $58,9 \%(\mathrm{~N}=93)$ & $52,8 \%(\mathrm{~N}=208)$ & \\
\hline megfelelő & $17,8 \%(\mathrm{~N}=98)$ & $13,9 \%(\mathrm{~N}=22)$ & $19,3 \%(\mathrm{~N}=76)$ & \\
\hline rossz & $2,4 \%(\mathrm{~N}=13)$ & $0,6 \%(\mathrm{~N}=1)$ & $3,0 \%(\mathrm{~N}=12)$ & \\
\hline
\end{tabular}

A Mentális Egészség Kontinuum Skála - rövid változat (MEKS) magyarra fordításának folyamata

Az eredeti angol nyelvú mérôeszközt, annak leírását és pontos kiértékelését tartalmazó kéziratot (Keyes, 2009b) Corey L. M. Keyes bocsátotta Reinhardt Melinda rendelkezésére, egyben megadta számára a kérdôív magyar adaptációjához és használatához szükséges engedélyt is. A magyar változatot - szabályos fordítási folyamattal, visszafordítással is kiegészítve - Reinhardt Melinda és Kökönyei Gyöngyi készítették el 2011-ben. A magyar nyelvú kérdôívet, mely megtalálható a függelékben, Mentális Egészség Kontinuum Skála - rövid változatnak (MEKS) neveztük el. A MEKS mind szerkezetében, mind tartalmában megegyezik az eredeti változattal, az MHC-SF-fel. Az MHC-SF részletes leírását az elméleti bevezetố tartalmazza. Kutatási célokra az eredeti amerikai és a magyar változat egyaránt szabadon felhasználható. 
Majdnem Tökéletes Skála - rövid változat

A Majdnem Tökéletes Skála rövidített változata (Short Almost Perfect Scale, SAPS; Rice, Richardson és Tueller, 2014) a vonásszintú perfekcionizmust és annak két jól elkülöníthetô - adaptív és maladaptív - formáját méri fel. A 8 tételes kérdôív két alskálája a Standardok (Törekvések), amely a magas személyes teljesítményelvárásokra utal, és a Diszkrepancia, amely a személyes standardoktól való észlelt távolságot és az ezzel kapcsolatos aggodalmakat összegzi. Előbbi skála a perfekcionizmus adaptív jellemzóit tükrözi, utóbbi az alkalmazkodást nehezítô jellegét. A tételeket egy hétfokozatú skálán értékeli 1-tôl (Egyáltalán nem értek egyet) 7-ig (Teljes mértékben egyetértek) a kitöltő, fordított tétel nincs. A teljes kérdôíven elérhetó minimum pontszám 8, a maximum 56 pont. A Standardok és a Diszkrepancia alskálákon egyaránt minimum 4, maximum 28 pont szerezhetô. A két alskála között az együtt járás a vizsgálatok alapján fordított irányú, de nem szignifikáns (pl. Rice és mtsai, 2014). A skála pszichometriai szempontból kiváló mutatókkal bír: a magas reliabilitás- és megfelelố validitáseredmények mellett a megerôsítô faktorelemzés (Factor mixture modeling, FMMs) és a látens klaszterezés is egy kétfaktoros (Standardok és Diszkrepancia) és háromosztályos (adaptív, maladaptív és nem perfekcionista csoportok) modellt tudott megerôsíteni (Rice és mtsai, 2014). A mérốeszköz mind serdülő (Reinhardt, Tóth és Rice, 2019), mind felnôtt (Reinhardt, Rice és Tóth, 2019) magyar mintákon hasonlóan jó pszichometriai jellemzóket mutatott, mint az eredeti amerikai változat. A kérdóívet magyarra az eredeti szerzók engedélyével Reinhardt Melinda és Tóth László fordította 2016-ban.

Depresszió, Szorongás és Stressz Kérdôiv (Depression Anxiety Stress Scales, DASS-21)

A DASS-21 (Henry és Crawford, 2005) a 42 tételes Depression Anxiety Stress Scales (DASS; Lovibond és Lovibond, 1995) rövidített, 21 tételes változata. A kérdôív három skálája önjellemzéses alapon hét-hét tétellel méri fel a depresszív (pl. diszfóriás hangulat, reménytelenség), a szorongásos (pl. vegetatív arousal, helyzeti szorongás) és a stressz (pl. irritabilitás, kikapcsolódás nehézsége) tüneteket, azonban ezek diagnosztizálására önmagában nem alkalmas. A tüneteket négy fokozat $(0=$ Egyáltalán nem alkalmazható és 3 = Nagyon gyakran alkalmazható) és az elmúlt egy hét alapján kell megítélnie a kitöltônek. Az egyes skálákon minimum 0, maximálisan 21 pont érhetô el. A méróeszköz megbízhatósága kiváló, ahogyan validitása is igazolást nyert (pl. Henry és Crawford, 2005; Szabó, 2010). Henry és Crawford (2005) az eredeti DASS háromfaktoros struktúráját erôsítette meg a DASS-21 esetében is egy átfogó, másodrendú pszichológiai distressz faktor jelenlétével együtt. A magyar változatot Szabó Marianna készítette el (Szabó, 2010).

\section{Kognitív Érzelem Reguláció Kérdốv - rövid változat}

A Kognitív Érzelem Reguláció Kérdôív rövid formája (Short version of the Cognitive Emotion Regulation Questionnaire, CERQ-short; Garnefski és Kraaij, 2006) 18 tételból áll. Megórizte az eredeti kérdôív (Cognitive Emotion Regulation Questionnaire, CERQ; Garnefski, Kraaij és Spinhoven, 2001) 9 skáláját, azonban a rövid formában az 
egyes skálák már csak két-két tételt tartalmaznak. A mérôeszköz azokat a kognitív folyamatokat térképezi fel, melyeket a személyek a stresszes élethelyzetekben kiváltódó érzelmeik szabályozására alkalmazhatnak. A kilenc skála közül öt adaptív érzelemregulációs stratégiákat mér fel: elfogadás; pozitív fókuszváltás; tervezés; átértékelés; perspektívába helyezés, míg négy skála az érzelemszabályozás maladaptív formáit méri: önvád; rumináció; katasztrofizálás; mások hibáztatása. A tételeket egy 5-fokú skálán értékelik a kitöltốk ( 1 = szinte soha és 5 = szinte mindig). Mind az eredeti hosszú (Garnefski és mtsai, 2001), mind a rövid változat (Garnefski és Kraaij, 2006) pszichometriailag jól múködő skálák. A rövid változatot bevezetô tanulmányban (Garnefski és Kraaij, 2006) az egyes alskálák Cronbach-alfa mutatói 0,62 és 0,85 között változtak. A gyengébb reliabilitásmutatók összefüggésben állhatnak azzal, hogy az egyes alskálákat kevés, csupán két-két tétel építi fel. Az eredeti változat (CERQ) magyar adaptációja Miklósi és munkatársai (Miklósi, Martos, Kocsis-Bogár és Perczel Forintos, 2011) munkája, melynek során a mérôeszköz hazai alkalmazhatóságát egyértelmúen alátámasztották. Vizsgálatukban a 9 alskála reliabilitási adatai (Cr- $\alpha$ ) 0,68 és 0,88 között mozogtak.

\section{Big Five Személyiségleltár-2 (Big Five Inventory-2)}

A Big Five személyiségvonások (extraverzió, barátságosság, lelkiismeretesség, érzelmi instabilitás, nyitottság) mérésére alkalmas Big Five Inventory-2 (BFI-2, Soto és John, 2017) egy 60 tételes mérôeszköz. A tételeket egy 5-fokú skálán értékelik a kitöltôk ( 1 = egyáltalán nem értek egyet és 5 = teljesen egyetértek). A BFI-2 a BFI (John, 1989) jelentôs és szigorú revíziója nyomán jött létre. A kutatók célja egy statisztikai szempontból robusztusabb Big Five mérôeszköz létrehozása volt. A BFI-2 kiváló pszichometriai tulajdonságokkal rendelkezik (Soto és John, 2017). A magyar fordítást Kun Ágota és Vass Zoltán készítette.

\section{Eljárás}

A keresztmetszeti kutatás során 2018 és 2019 márciusa között kényelmi mintavétellel, online toborzással hazai felsôoktatási intézményekben tanulmányokat folytató hallgatókat értünk el. Az anonim kutatásban való részvételt - bármiféle jutalom vagy javadalmazás nélkül - önkéntesen vállaló egyetemisták egy interneten keresztül elérhetô, hat kérdőívbôl álló tesztcsomagot töltöttek ki.

\section{Statisztikai elemzés}

A mérőeszközök alapadatainak (skálaátlag és szórás) és a demográfiai adatok megadása mellett azokat független mintás t-próbával és Khí-négyzet próbával hasonlítottuk össze a férfiak és a nốk csoportjában. Az összefüggések erôsségét Cohen-d hatásméretmutatóval (Cohen, 1992) becsültük. A kérdőívek belsố konzisztenciáját a Cronbachalfa mutatóval adtuk meg. A tanulmányban validálni kívánt skála (MEKS) konvergens és diszkrimináns validitását Pearson-féle korrelációs elemzéssel, Bonferroni-korrekci- 
óval kiegészítve teszteltük. A MEKS kérdôív alapján azonosított három szubjektív jóllét csoportot (virágzók, mérsékelt mentális egészséggel bírók, hervadók, Keyes, 2002a) egyszempontos ANOVA-val, $\eta^{2}$ hatásméret-mutatóval kiegészítve hasonlítottuk össze a mentális betegségtünetek, az adaptív és a maladaptív kognitív érzelemszabályozó stratégiák és bizonyos személyiségvonások (Big Five és perfekcionizmus) mentén. Ezeket az elemzéseket az SPSS 26.0 statisztikai programmal végeztük el.

A validációs folyamat részeként a MEKS kérdőív megerôsítő faktorelemzését (Confirmatory Factor Analysis, CFA és Exploratory Structural Equation Modeling, ESEM), a legjobban illeszkedô faktorszerkezet kiválasztását, valamint a nem és életkor szerinti skaláris, metrikus és konfigurális invariancia tesztelését is elvégeztük. Míg a CFA esetében a kereszttöltéseket 0-ban rögzítjük, addig az ESEM keretrendszerében - az a priori modellek tesztelése mellett - a kereszttöltéseket elózetesen 0-hoz közelítve specifikáljuk (target rotation), az ESEM alkalmazásával így az egyes, CFA-val becsült szubjektív jóllét faktorok közötti esetleges magas korreláció csökkenhet. Az ESEM használatát az is támogatta, hogy az egyes szubjektív jóllét faktorok összefügghetnek (pl. az érzelmi és a pszichológiai jóllét) (ld. pl. Rogoza és mtsai, 2018), s tételeik nem feltétlen csak egyetlen faktorra töltôdnek erôteljesebben. Az ESEM eljárással így reálisabb kép rajzolódhat ki a faktorszerkezetrôl. A maximum likelihood becslési eljárás normális eloszlás előfeltételének sérülésére annak robusztus alternatív becslési eljárását - maximum likelihood robust to non-normality (MLR) - használtuk. Az egyes modellek illeszkedését többféle illeszkedési mutatóval teszteltük. A Comparative Fit Index (CFI) és a Tucker-Lewis Index (TLI) esetében a 0,95 vagy az afölötti értéket, míg a Root Mean Square Error of Approximation (RMSEA) mutató esetében a 0,05 vagy az annál kisebb értéket tekintettük megfelelőnek. Ezeket az elemzéseket az Mplus 8.0 (Muthén és Muthén 1998-2017) statisztikai programcsomaggal hajtottuk végre.

A szignifikanciaszintet általánosságban 95\%-os megbízhatósági szinten határoztuk meg, korrelációs elemzések esetében pedig Bonferroni-korrekció alapján.

\section{Etikai vonatkozások}

A tanulmányban bemutatott kutatás etikai engedélyét az Eötvös Loránd Tudományegyetem Pedagógiai és Pszichológiai Kar Kutatásetikai Bizottsága adta ki 2018-ban. A kutatást a vizsgálatvezetôk a Helsinki Nyilatkozat (WHO, 2001) etikai alapelveivel összhangban tervezték meg és hajtották végre. Ennek megfelelốen a tesztcsomagot csak azok a 18 éven felüli, felsốoktatásban tanuló hallgatók tölthették ki, akik a kérdôívcsomag kitöltésének megkezdése elôtt írásos informált beleegyezésüket adták a vizsgálatban való részvételükhöz. A kérdőívek kitöltése önkéntes alapon és névtelenül zajlott. 


\section{EREDMÉNYEK}

\section{A vizsgálat alapstatisztikája}

A felhasznált mérôeszközök alapstatisztikáit, valamint a nemi különbségeket tesztelô próbastatisztikákat a 2. táblázatban mutatjuk be. Mindegyik kérdôív belsố konzisztenciája teljesíti az elvárt 0,70-es szintet (Nunnually, 1978), a CERQ Tervezés alskálájának kivételével, mely csak közelíti azt. Az utóbbi alskálával kapott eredményeket ezért óvatossággal szükséges kezelni az értelmezés során.

Az egyes skálaértékek csoportátlagainak nemenkénti összehasonlítása szerint a férfiak és a nôk nem különböznek a pozitív mentális egészség mutatói (MEKS skálaátlagok) tekintetében. Hasonlóképpen nincs nemi különbség a depressziós és szorongásos tünetek átlagában sem, ugyanakkor a nốk magasabb stressz-szintet jeleztek. Az adaptív kognitív érzelemregulációs technikák alkalmazásában csak a perspektívába helyezés tekintetében van eltérés, a nôk azt kifejezettebben alkalmazzák. A maladaptív érzelemregulációs módok tekintetében a nôk magasabb rumináció- és katasztrofizálásértékekkel jellemezhetôk, mint a férfiak, ugyanakkor kevésbé hajlamosak mások hibáztatására. A nôk továbbá szignifikánsan magasabb perfekcionizmusszinttel jellemezhetôk a férfiakhoz képest: mind a vonásszintú perfekcionizmust összességében, mind annak két összetevôjét (Standardok és Diszkrepancia) tekintve. Végül, a Big Five személyiségvonások tekintetében a nôk általánosságban barátságosabbnak, lelkiismeretesebbnek és nyitottabbnak bizonyultak, mint a férfiak, ugyanakkor neuroticizmuspontszámuk is szignifikánsan magasabb, mint a férfiaké. A nemi különbségek tesztelésénél a hatásméret-mutatók egyik esetben sem érték el a közepes erôsségú szintet, azaz a nemek közötti különbség kimutatható ugyan, de nem markáns (2. táblázat).

\section{A megerösitó faktorelemzés eredményei}

A legjobban illeszkedő faktorszerkezet kiválasztása érdekében hat modellt vizsgáltunk: (1) egy CFA-val tesztelt egyfaktoros megoldást; (2) egy CFA-val tesztelt kétfaktoros megoldást; (3) egy CFA-val tesztelt háromfaktoros megoldást, amely az eredeti Keyes-féle faktorszerkezettel azonos (Keyes, 2002a); (4) egy háromfaktoros megoldást ESEM-elemzéssel, melyben a tételek kereszttöltéseit is becsülni tudjuk; (5) egy CFA-val tesztelt bifaktoros modellt és végül (6) egy ESEM-elemzéssel tesztelt bifaktoros modellt. A versengó modellekhez tartozó illeszkedési mutatókat a 3. táblázat foglalja öszsze. A modellek összehasonlítása alapján a bifaktoros ESEM-modell megtartása javasolt, mert a Khí-négyzet különbségtesztek alapján ez a modell mutatja a legkiválóbb illeszkedést a háromfaktoros ESEM- és a bifaktoros CFA-megoldásokhoz képest. Az egy-, a két- és a háromfaktoros CFA-megoldások illeszkedési mutatói nem voltak megfelelôk (3. táblázat).

A bifaktoros ESEM-modellhez tartozó faktortöltések és reliabilitásmutatók (4. táblázat) egy domináns, általános szubjektív jóllét faktor jelenlétét jelzik. Mind a 14 tétel jelentôs faktortöltéssel súlyozódik erre az általános faktorra. Kirajzolódik továbbá a három nagy szubjektív jóllét kör, azonban az érzelmi jóllét kivételével a specifikus 
2. táblázat. A vizsgálatban szereplő skálák és alskálák megbízhatósági és leíró statisztikai mutatói és összehasonlításuk a nemek tekintetében

\begin{tabular}{|c|c|c|c|c|c|c|}
\hline Változó & $\begin{array}{c}\text { Teljes minta } \\
N=552 \\
\text { Átlag } \\
\text { (SD) }\end{array}$ & $\begin{array}{l}\text { Férfiak } \\
N=158 \\
\text { Átlag } \\
\text { (SD) }\end{array}$ & $\begin{array}{c}\text { Nók } \\
N=394 \\
\text { Átlag } \\
\text { (SD) }\end{array}$ & $\begin{array}{l}\text { A csoportok közöt- } \\
\text { ti különbséget jelzô } \\
\text { próbastatisztika }\end{array}$ & Cohen-d & $\mathrm{Cr}-\alpha$ \\
\hline MHC össz & $\begin{array}{c}40,92 \\
(12,03)\end{array}$ & $\begin{array}{c}41,19 \\
(13,07)\end{array}$ & $40,82(11,60)$ & $\mathrm{t}_{(550)}=0,33 ; \mathrm{p}=0,742$ & 0,03 & 0,89 \\
\hline MHC Érzelmi jóllét & $9,47(3,22)$ & $9,35(3,35)$ & $9,52(3,17)$ & $\mathrm{t}_{(550)}=0,54 ; \mathrm{p}=0,590$ & 0,05 & 0,87 \\
\hline MHC Pszichés jóllét & $19,73(5,89)$ & $19,68(6,34)$ & $19,75(5,71)$ & $\mathrm{t}_{(550)}=0,13 ; \mathrm{p}=0,898$ & 0,01 & 0,84 \\
\hline MHC Társas jóllét & $11,72(4,87)$ & $12,16(5,23)$ & $11,55(4,72)$ & $\mathrm{t}_{(550)}=1,32 ; \mathrm{p}=0,186$ & 0,13 & 0,72 \\
\hline DASS Depresszió & $5,70(5,14)$ & $5,69(5,10)$ & $5,70(5,16)$ & $\mathrm{t}_{(550)}=0,02 ; \mathrm{p}=0,982$ & 0 & 0,91 \\
\hline DASS Szorongás & $4,68(4,38)$ & $4,30(4,05)$ & $4,84(4,51)$ & $\mathrm{t}_{(550)}=1,30 ; \mathrm{p}=0,193$ & 0,12 & 0,83 \\
\hline DASS Stressz & $8,01(4,95)$ & $6,73(4,40)$ & $8,52(5,07)$ & $\mathrm{t}_{(550)}=3,87 * * *$ & 0,37 & 0,86 \\
\hline CERQ Elfogadás & $6,58(2,09)$ & $6,51(2,06)$ & $6,61(2,11)$ & $\mathrm{t}_{(550)}=0,52 ; \mathrm{p}=0,602$ & 0,05 & 0,81 \\
\hline $\begin{array}{l}\text { CERQ Pozitív } \\
\text { fókuszváltás }\end{array}$ & $4,88(2,17)$ & $4,95(2,20)$ & $4,85(2,15)$ & $\mathrm{t}_{(550)}=0,50 ; \mathrm{p}=0,618$ & 0,05 & 0,87 \\
\hline CERQ Tervezés & $6,91(1,80)$ & $6,81(1,73)$ & $6,96(1,83)$ & $\mathrm{t}_{(550)}=0,87 ; \mathrm{p}=0,388$ & 0,08 & 0,63 \\
\hline CERQ Átértékelés & $6,83(2,11)$ & $6,74(1,96)$ & $6,87(2,17)$ & $\mathrm{t}_{(550)}=0,63 ; \mathrm{p}=0,529$ & 0,06 & 0,75 \\
\hline CERQ Perspektíva & $6,10(2,09)$ & $5,70(2,07)$ & $6,26(2,07)$ & $\mathrm{t}_{(550)}=2,87 * *$ & 0,28 & 0,72 \\
\hline CERQ Önvád & $5,70(2,05)$ & $5,56(1,97)$ & $5,76(2,07)$ & $\mathrm{t}_{(550)}=1,06 ; \mathrm{p}=0,289$ & 0,10 & 0,69 \\
\hline CERQ Rumináció & $6,89(2,22)$ & $6,16(2,32)$ & $7,19(2,11)$ & $\mathrm{t}_{(550)}=5,01 * * *$ & 0,47 & 0,86 \\
\hline $\begin{array}{l}\text { CERQ Katasztrofi- } \\
\text { zálás }\end{array}$ & $4,63(2,16)$ & $4,26(2,06)$ & $4,78(2,18)$ & $\mathrm{t}_{(550)}=2,58 * *$ & 0,24 & 0,86 \\
\hline $\begin{array}{l}\text { CERQ Mások } \\
\text { hibáztatása }\end{array}$ & $3,86(1,64)$ & $4,17(1,80)$ & $3,73(1,55)$ & $\mathrm{t}_{(550)}=2,89 * *$ & 0,27 & 0,79 \\
\hline SAPS össz & $38,88(9,20)$ & $36,20(9,25)$ & $39,96(8,97)$ & $\mathrm{t}_{(550)}=4,41 * * *$ & 0,42 & 0,86 \\
\hline SAPS Standardok & $22,00(4,68)$ & $20,68(4,97)$ & $22,53(4,45)$ & $\mathrm{t}_{(550)}=4,28 * * *$ & 0,40 & 0,86 \\
\hline SAPS Diszkrepancia & $17,43(5,96)$ & $15,53(5,78)$ & $17,43(5,95)$ & $\mathrm{t}_{(550)}=3,42 * *$ & 0,32 & 0,85 \\
\hline BFI2 Extraverzió & $39,77(8,70)$ & $39,73(8,38)$ & $39,78(8,84)$ & $\mathrm{t}_{(535)}=0,07 ; \mathrm{p}=0,948$ & 0,01 & 0,87 \\
\hline BFI2 Barátságosság & $42,87(6,88)$ & $41,09(6,87)$ & $43,57(6,77)$ & $\mathrm{t}_{(535)}=3,82 * * *$ & 0,37 & 0,80 \\
\hline $\begin{array}{l}\text { BFI2 Lelkiismere- } \\
\text { tesség }\end{array}$ & $41,10(7,54)$ & $38,86(6,96)$ & $41,98(7,59)$ & $\mathrm{t}_{(535)}=4,40 * * *$ & 0,42 & 0,83 \\
\hline $\begin{array}{l}\text { BFI2 Érzelmi } \\
\text { instabilitás }\end{array}$ & $36,85(8,58)$ & $34,02(8,35)$ & $37,97(8,42)$ & $\mathrm{t}_{(535)}=4,91 * * *$ & 0,47 & 0,87 \\
\hline BFI2 Nyitottság & $45,43(7,95)$ & $43,97(8,41)$ & $46,00(7,69)$ & $\mathrm{t}_{(535)}=2,68 * *$ & 0,26 & 0,85 \\
\hline
\end{tabular}

Megjegyzés: *p $<0,05 ; * *<0,01 ; * * * \mathrm{p}<0,0001$.

A hatásméret mutató (Cohen-d) értékeit Cohen (1992) alapján az alábbiak szerint értelmeztük: 0,20: kis hatás, 0,50: közepes hatás, 0,80: nagy mértékü hatás. Cr- $\alpha=$ Cronbach- $\alpha$.

MHC = Mental Health Continuum-Short Form, Mentális Egészség Kontinuum Skála. DASS = Depression Anxiety Stress Scales 21 itemes változat. CERQ = CERQ-short, Cognitive Emotion Regulation Questionnaire-short; Kognitív Érzelem-Reguláció Kérdőív rövid formája. SAPS = Short Almost Perfect Scale, Majdnem Tökéletes Skála rövidített változata. BFI2 = Big Five Inventory-2. 


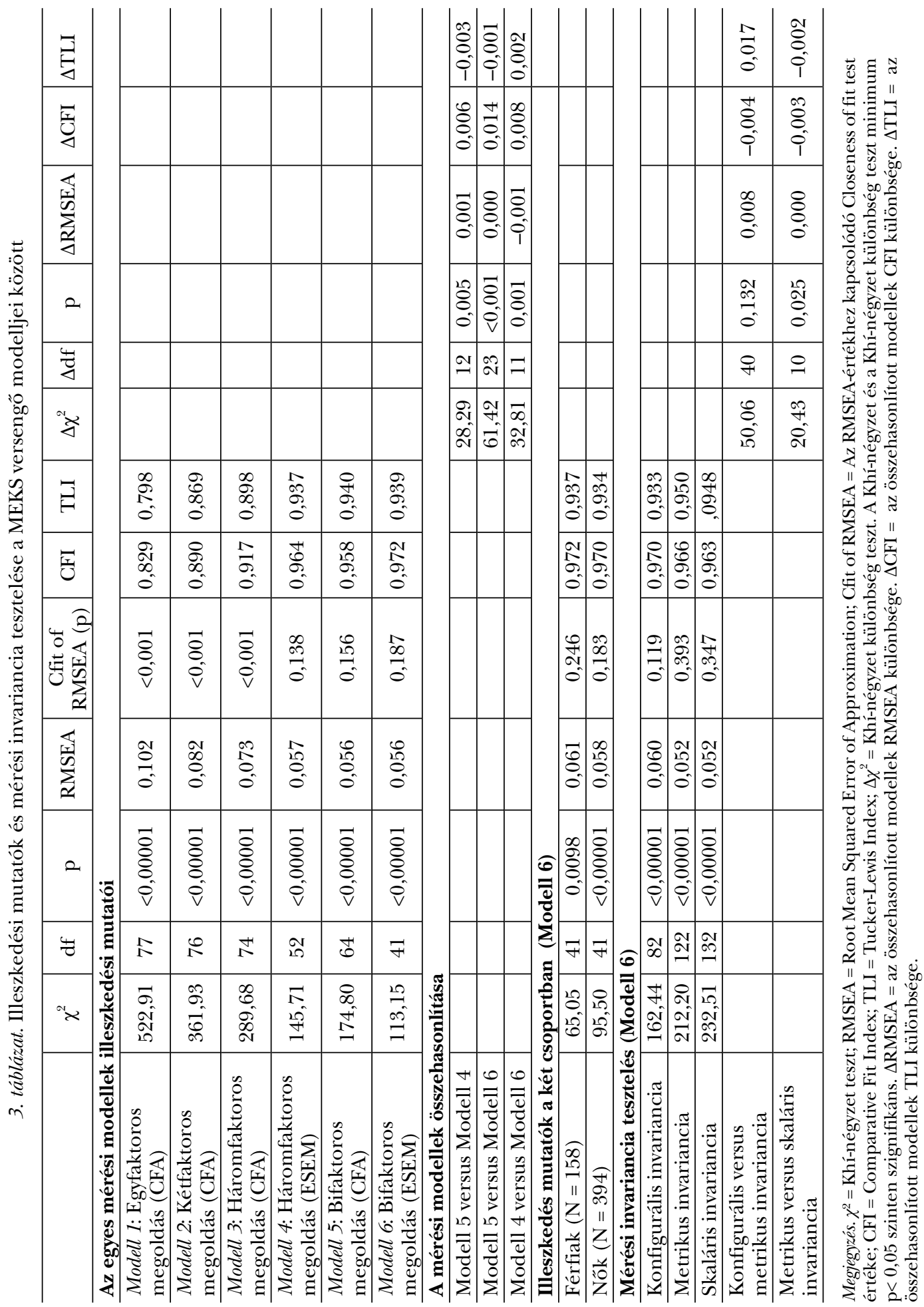


faktorokon (pszichológiai és társas jóllét) elófordul, hogy egy-egy tétel esetében alacsony vagy egy esetben (4. tétel) nem szignifikáns faktortöltés is megjelenik. A modellalapú reliabilitásmutatók (hierarchikus ómega és relatív ómega) is alátámasztják az általános faktor erôs hatását. Abban az esetben ugyanis, ha egyszerre vesszük figyelembe az általános és a specifikus faktorokat (ómegaérték), akkor megfelelôen kirajzolódik a három specifikus faktor. Amennyiben azonban kiszúrjük az általános faktor hatását, akkor a reliabilitásértékek (hierarchikus ómega) csökkennek. A specifikus faktorok értékei tehát az általános faktor hatásától kevéssé függetlenek (relatív ómegaértékek).

A legjobban illeszkedô modell (bifaktoros ESEM-modell) esetében a nemi invarianciát is teszteltük. Az egyes invarianciamodellek külön-külön is megfelelő illeszkedést mutatnak. Eredményeink szerint a két nem között elfogadható a skaláris invariancia feltétele, tehát a faktorszerkezet, a faktortöltések és az átlagok is hasonlóak a két nem esetében (4. táblázat).

4. táblázat. Standardizált faktortöltések és reliabilitásadatok a bifaktoros ESEM megoldás (Modell 6) esetén

\begin{tabular}{l|r|r|r|c}
\hline Tétel & $\mathrm{GWB}^{\mathrm{a}}$ & $\mathrm{EWB}^{\mathrm{b}}$ & $\mathrm{SWB}^{\mathrm{c}}$ & $\mathrm{PWB}^{\mathrm{d}}$ \\
\hline 1 & $\mathbf{0 , 6 5}$ & $\mathbf{0 , 4 7}$ & $-0,02$ & 0,13 \\
\hline 2 & $\mathbf{0 , 6 5}$ & $\mathbf{0 , 5 3}$ & $-0,01$ & $-0,01$ \\
\hline 3 & $\mathbf{0 , 7 2}$ & $\mathbf{0 , 4 6}$ & 0,01 & 0,06 \\
\hline 4 & $\mathbf{0 , 7 2}$ & $\mathbf{- 0 , 2 0}$ & $-0,04$ & $-0,24$ \\
\hline 5 & $\mathbf{0 , 5 4}$ & 0,04 & $\mathbf{0 , 1 3}$ & 0,19 \\
\hline 6 & $\mathbf{0 , 5 6}$ & $-0,06$ & $\mathbf{0 , 4 9}$ & $-0,13$ \\
\hline 7 & $\mathbf{0 , 3 8}$ & 0,07 & $\mathbf{0 , 7 1}$ & 0,00 \\
\hline 8 & $\mathbf{0 , 3 2}$ & $\mathbf{- 0 , 1 2}$ & $\mathbf{0 , 4 0}$ & 0,06 \\
\hline 9 & $\mathbf{0 , 6 5}$ & $\mathbf{0 , 1 3}$ & 0,07 & 0,34 \\
\hline 10 & $\mathbf{0 , 5 7}$ & $\mathbf{0 , 1 3}$ & $-0,08$ & 0,26 \\
\hline 11 & $\mathbf{0 , 5 5}$ & $\mathbf{0 , 1 0}$ & 0,05 & 0,35 \\
\hline 13 & $\mathbf{0 , 6 5}$ & $-0,05$ & 0,06 & 0,16 \\
\hline 14 & $\mathbf{0 , 6 4}$ & $-0,10$ & $-\mathbf{0 , 0 9}$ & 0,40 \\
\hline Omega & $\mathbf{0 , 6 9}$ & 0,08 & $-0,01$ & 0,24 \\
\hline Hierarchikus & 0,92 & 0,87 & 0,79 & 0,85 \\
\hline Omega & 0,82 & 0,30 & 0,26 & 0,15 \\
\hline Relatív Omega & \\
\hline
\end{tabular}

Megjegyzés. A p < 0,05 szinten szignifikáns faktortöltések félkövérrel szedve. A jelentôs (0,30 feletti) faktortöltésû́ tételek szürke háttérrel megjelenítettek. ${ }^{a}$ Általános jóllét. ${ }^{b}$ Érzelmi jóllét. ${ }^{c}$ Szociális jóllét. ${ }^{\mathrm{d}}$ Pszichológiai jóllét. ${ }^{\mathrm{e}}$ Relatív Omega = Hierarchikus Omega / Omega.

\section{A vizsgált változók együtt járásai - A MEKS validitási adatai}

A teljes MEKS-sel annak alskálái (érzelmi, pszichológiai és társas jóllét) erôs korrelációt mutatnak. Az egyes alskálák egymással közepes erôsséggel járnak együtt (5. táblázat). 
5. táblázat. A MEKS skálák korrelációi a teljes mintában

\begin{tabular}{l|c|c|c}
\hline & 2. & 3. & 4. \\
\hline 1. MHC össz & $0,810^{* * *}$ & $0,913^{* * *}$ & $0,828^{* * *}$ \\
\hline 2. MHC Érzelmi jóllét & - & $0,692^{* * *}$ & $0,503^{* * *}$ \\
\hline 3. MHC Pszichés jóllét & & - & $0,588^{* * *}$ \\
\hline 4. MHC Társas jóllét & & & - \\
\hline
\end{tabular}

Megjegyzés. N=552. MHC = Mental Health Continuum-Short Form, Mentális Egészség Kontinuum Skála. $* \mathrm{p}<0,05 ; * * \mathrm{p}<0,01 ; * * * \mathrm{p}<0,001$.

Az elvártaknak megfelelően a pozitív mentális egészség mutatók (teljes MEKS és alskálái) a depresszív, a szorongásos és a stressztünetekkel közepes mértékben, fordított irányban járnak együtt. Kivétel ez alól a társas jóllét területe, mely a mentális betegségtünetekkel gyenge negatív korrelációt mutat. A perfekcionista törekvésekkel (Standardok) egyik szubjektív jóllét skála sincs kapcsolatban, ugyanakkor a perfekcionista törekvések és a teljesítmény között észlelt távolság (Diszkrepancia) mind a négy szubjektív jóllét mutatóval gyengén, fordított irányban korrelál. A Big Five személyiségvonások tekintetében a szubjektív jóllét területei mind az öt nagy személyiségjellemzôvel gyenge vagy közepes kapcsolatban vannak. Összességében elmondhatjuk, minél kifejezettebb a szubjektív jóllét (és annak összetevôi), annál extravertáltabb, barátságosabb, lelkiismeretesebb, nyitottabb, emocionálisan pedig stabilabb a személy és fordítva. Ez alól kivételt az érzelmi jóllét és a nyitottság kapcsolatának hiánya jelent (6. táblázat).

Általánosságban a szubjektív jóllét mutatók és az adaptív érzelemregulációs mechanizmusok szintén gyenge vagy közepes, pozitív együtt járást mutatnak. A társas jóllét azonban az érzelmek elfogadásával és a tervezéssel nincs kapcsolatban. Szintén az elvártaknak megfelelóen a maladaptív érzelemregulációs stratégiákkal a szubjek-

6. táblázat. A MEKS skálák összefüggései a mentális betegségtünetekkel és bizonyos személyiségvonásokkal a teljes mintában

\begin{tabular}{|c|c|c|c|c|c|c|c|c|c|c|}
\hline & $\begin{array}{c}\text { DASS } \\
\text { Depresszió }\end{array}$ & $\begin{array}{c}\text { DASS } \\
\text { Szorongás }\end{array}$ & $\begin{array}{l}\text { DASS } \\
\text { Stressz }\end{array}$ & $\begin{array}{c}\text { SAPS } \\
\text { Standardok }\end{array}$ & $\begin{array}{c}\text { SAPS } \\
\text { Disz- } \\
\text { krepancia }\end{array}$ & $\begin{array}{c}\text { BFI2 } \\
\text { Extraverzió }\end{array}$ & $\begin{array}{c}\text { BFI2 } \\
\text { Barátsá- } \\
\text { gosság }\end{array}$ & $\begin{array}{c}\text { BFI2 } \\
\text { Lelkiisme- } \\
\text { retesség }\end{array}$ & $\begin{array}{c}\text { BFI2 } \\
\text { Érzelmi in- } \\
\text { stabilitás }\end{array}$ & $\begin{array}{c}\text { BFI2 } \\
\text { Nyitott- } \\
\text { ság } \\
\end{array}$ \\
\hline $\begin{array}{l}\text { MHC } \\
\text { össz }\end{array}$ & $-0,588^{* * *}$ & $-0,360^{* * *}$ & $-0,364^{* * * *}$ & 0,047 & $-0,325^{* * *}$ & $0,451^{* * *}$ & $0,277^{* *}$ & $0,301^{* *}$ & $-0,557^{* * *}$ & $0,191^{* *}$ \\
\hline $\begin{array}{l}\text { MHC } \\
\text { Érzelmi } \\
\text { jóllét }\end{array}$ & $-0,587^{* * *}$ & $-0,377^{* * *}$ & $-0,409 * * *$ & $-0,019$ & $-0,349^{* * *}$ & $0,286^{* * *}$ & $0,199^{* *}$ & $0,248^{* *}$ & $-0,530 * * *$ & $0,100^{*}$ \\
\hline $\begin{array}{l}\text { MHC } \\
\text { Pszichés } \\
\text { jóllét }\end{array}$ & $-0,597^{* * *}$ & $-0,373^{* * *}$ & $-0,340^{* * * *}$ & 0,083 & $-0,343^{* * *}$ & $0,499 * * *$ & $0,251^{* *}$ & $0,354^{* *}$ & $-0,541 * * *$ & $0,230 * *$ \\
\hline $\begin{array}{l}\text { MHC } \\
\text { Társas } \\
\text { jóllét }\end{array}$ & $-0,341^{* * *}$ & $-0,188^{* * *}$ & $-0,217 * * *$ & 0,028 & $-0,156^{* * *}$ & $0,318^{* * *}$ & $0,247 * *$ & $0,150^{* *}$ & $-0,367 * * *$ & $0,126^{* *}$ \\
\hline
\end{tabular}

Megjegyzés. $\mathrm{N}=552$. MHC = Mental Health Continuum-Short Form, Mentális Egészség Kontinuum Skála. DASS = Depression Anxiety Stress Scales 21 itemes változat. SAPS = Short Almost Perfect Scale, Majdnem Tökéletes Skála rövidített változata. BFI2 = Big Five Inventory-2. ${ }^{*} \mathrm{p}<0,05 ;{ }^{* *} \mathrm{p}<0,01 ;{ }^{* * *} \mathrm{p}<0,001$. Vastaggal szedve a Bonferroni-korrekciót $(\mathrm{p}<0,0035)$ követően is szignifikáns értékek. 
7. táblázat. A MEKS skálák összefüggései a kognitív érzelemszabályozás stratégiáival a teljes mintában

\begin{tabular}{|c|c|c|c|c|c|c|c|c|c|}
\hline & $\begin{array}{l}\text { CERQ El- } \\
\text { fogadás }\end{array}$ & $\begin{array}{c}\text { CERQ } \\
\text { Pozitív } \\
\text { fókusz- } \\
\text { váltás }\end{array}$ & $\begin{array}{c}\text { CERQ } \\
\text { Tervezés }\end{array}$ & $\begin{array}{l}\text { CERQÁt- } \\
\text { értékelés }\end{array}$ & $\begin{array}{c}\text { CERQ } \\
\text { Perspek- } \\
\text { tíva }\end{array}$ & $\begin{array}{l}\text { CERQ } \\
\text { Önvád }\end{array}$ & $\begin{array}{l}\text { CERQ } \\
\text { Rumi- } \\
\text { náció }\end{array}$ & $\begin{array}{c}\text { CERQ } \\
\text { Katasztro- } \\
\text { fizálás }\end{array}$ & $\begin{array}{l}\text { CERQ } \\
\text { Mások hi- } \\
\text { báztatása }\end{array}$ \\
\hline MHC össz & $0,138 * * *$ & $0,196^{* * * *}$ & $0,184^{* * *}$ & $0,381 * * *$ & $0,253 * * *$ & $-0,328 * * *$ & $-0,202 * * *$ & $-0,340 * * *$ & $-0,132 * *$ \\
\hline MHC Érzelmi jóllét & $0,129 * *$ & $0,181 * * *$ & $0,139 * * *$ & $0,272 * * *$ & $0,232 * * *$ & $-0,308 * * *$ & $-0,206 * * *$ & $-0,359 * * *$ & $-0,147 * * *$ \\
\hline MHC Pszichés jóllét & $0,144 * * *$ & $0,160 * * *$ & 0,226 *** & $0,404 * * *$ & $0,261 * * *$ & $-0,331 * * *$ & $-0,186 * * *$ & $-0,335 * * *$ & $-0,133 * *$ \\
\hline MHC Társas jóllét & 0,081 & $0,171 * * *$ & $0,089 *$ & $0,271 * * *$ & $0,156^{* * *}$ & $-0,206 * * *$ & $-0,138^{* * *}$ & $-0,197 * * *$ & $-0,067$ \\
\hline
\end{tabular}

Megjegyzés. $\mathrm{N}=552$. MHC = Mental Health Continuum-Short Form, Mentális Egészség Kontinuum Skála. CERQ = CERQ-short, Cognitive Emotion Regulation Questionnaire-short; Kognitív Érzelem-Reguláció Kérdốv rövid formája. * $\mathrm{p}<0,05 ; * * \mathrm{p}<0,01 ; * * * \mathrm{p}<0,001$. Vastaggal szedve a Bonferroni-korrekciót $(\mathrm{p}<$ $0,0038)$ követôen is szignifikáns értékek.

tív jóllét területei gyenge, de fordított irányú korrelációt mutatnak fel. A társas jóllét területe azonban nincsen kapcsolatban a másokat hibáztató érzelemszabályozó attitûddel (7. táblázat).

\section{A mentális egészség kategoriális felosztásának (Keyes, 2002a) eredményei}

Keyes (2002a) alapján elvégeztük a mentális egészség dimenzionális vizsgálatát is a magyar egyetemista mintán. A teljes minta közel egyharmada $(30,1 \%)$ a legkiválóbb szubjektív jóllét szinttel jellemezte magát, ók az ún. virágzók. Az egyetemista csoport gerincét $(62,1 \%)$ a mérsékelt mentális egészséggel bírók adják, míg 7,8\%-uk kifejezetten alacsony szubjektív jóllét értékekkel bír, azaz ún. hervadó. Nemi különbség nem mutatható ki a pozitív mentális egészség kategóriáinak eloszlásában (8. táblázat).

A pozitív mentális egészség három kategóriáját (virágzók, mérsékelt mentális egészségúek és hervadók) összehasonlítottuk a mentális betegségtünetek, az érzelemszabályozás és bizonyos személyiségvonások mentén (9. táblázat). Az elvártaknak megfelelôen a legkevesebb mentális betegségtünetet (depresszív, szorongásos és stressztünetek) a virágzó egyének mutatják, óket követik a mérsékelt mentális egészséggel bírók, majd a hervadók. Itt a hatásméret-mutatók közepes, illetve erôs összefüggéseket jeleznek. Érdemes megjegyezni, hogy a hervadók átlagosan több mint négyszer annyi depresszív és majdnem háromszor annyi szorongásos tünetet észlelnek maguknál, mint a virágzók. Az érzelemszabályozást tekintve az elfogadás kognitív stratégiájában a csoportok

8. táblázat. A mentális egészség kategóriái a teljes mintában és a két nem esetében

\begin{tabular}{|c|c|c|c|c|}
\hline Változó* & $\begin{array}{c}\text { Teljes minta } \\
N=552 \\
\%(\mathrm{n})\end{array}$ & $\begin{array}{l}\text { Férfiak } \\
N=158 \\
\%(\mathrm{n})\end{array}$ & $\begin{array}{c}\text { Nók } \\
N=394 \\
\%(\mathrm{n})\end{array}$ & $\begin{array}{l}\text { A csoportok közötti } \\
\text { különbséget jelzô } \\
\text { próbastatisztika }\end{array}$ \\
\hline Virágzók & $30,1(166)$ & $31,0(49)$ & $29,7(117)$ & \multirow{3}{*}{$\chi^{2}(2)=1,99 ; p=0,368$} \\
\hline $\begin{array}{l}\text { Mérsékelt mentális } \\
\text { egészségúek }\end{array}$ & $62,1(343)$ & $58,9(93)$ & $63,5(250)$ & \\
\hline Hervadók & $7,8(43)$ & $10,1(16)$ & $6,9(27)$ & \\
\hline
\end{tabular}

Megjegyzés: *A mentális egészség kategóriái Keyes (2002a) felosztása alapján. 
9. táblázat. A mentális egészségkategóriák összehasonlítása a felmért változók tekintetében

\begin{tabular}{|c|c|c|c|c|c|}
\hline Változó & $\begin{array}{l}\text { Virágzók } \\
(\mathrm{N}=166)\end{array}$ & $\begin{array}{c}\text { Mérsékelt } \\
\text { mentális } \\
\text { egészségúek } \\
(\mathrm{N}=343)\end{array}$ & $\begin{array}{l}\text { Hervadók } \\
(\mathrm{N}=43)\end{array}$ & $\begin{array}{c}\text { Statisztikai próba értéke } \\
(\mathrm{p}) ; \\
\text { hatásméret mutató }\end{array}$ & $\begin{array}{c}\text { Csoportok } \\
\text { közötti } \\
\text { különbsé- } \\
\text { gek* }\end{array}$ \\
\hline DASS Depresszió & $2,89(3,44)$ & $6,11(4,70)$ & $13,26(5,34)$ & $\begin{array}{c}\mathrm{F}(2)=97,98(<0,0001) \\
\eta^{2}=0,26\end{array}$ & $\mathrm{~V}<\mathrm{M}<\mathrm{H}$ \\
\hline DASS Szorongás & $3,21(4,07)$ & $4,89(4,07)$ & $8,72(5,14)$ & $\begin{array}{c}\mathrm{F}(2)=31,03(<0,0001) \\
\eta^{2}=0,10\end{array}$ & $\mathrm{~V}<\mathrm{M}<\mathrm{H}$ \\
\hline DASS Stressz & $6,23(4,89)$ & $8,37(4,66)$ & $11,93(4,62)$ & $\begin{array}{c}\mathrm{F}(2)=27,58(<0,0001) \\
\eta^{2}=0,09\end{array}$ & $\mathrm{~V}<\mathrm{M}<\mathrm{H}$ \\
\hline CERQ Elfogadás & $6,87(2,13)$ & $6,50(2,07)$ & $6,12(2,07)$ & $\begin{array}{c}\mathrm{F}(2)=2,99(=0,051) \\
\eta^{2}=0,01\end{array}$ & $\mathrm{~V}=\mathrm{M}=\mathrm{H}$ \\
\hline CERQ Pozitív fókuszváltás & $5,16(2,30)$ & $4,86(2,10)$ & $3,93(1,90)$ & $\begin{array}{c}\mathrm{F}(2)=5,60 \quad(<0,01) \\
\eta^{2}=0,02\end{array}$ & $\mathrm{~V}=\mathrm{M}>\mathrm{H}$ \\
\hline CERQ Tervezés & $7,29(1,93)$ & $6,83(1,73)$ & $6,16(1,54)$ & $\begin{array}{c}\mathrm{F}(2)=7,92(<0,0001) \\
\eta^{2}=0,03\end{array}$ & $\mathrm{~V}>\mathrm{M}=\mathrm{H}$ \\
\hline CERQ Átértékelés & $7,81(1,93)$ & $6,57(2,04)$ & $5,14(1,61)$ & $\begin{array}{c}\mathrm{F}(2)=39,05(<0,0001) \\
\eta^{2}=0,13\end{array}$ & $\mathrm{~V}>\mathrm{M}>\mathrm{H}$ \\
\hline CERQ Perspektíva & $6,58(2,05)$ & $6,02(2,07)$ & $4,88(1,75)$ & $\begin{array}{c}\mathrm{F}(2)=12,40 \quad(<0,0001) \\
\eta^{2}=0,04\end{array}$ & $\mathrm{~V}>\mathrm{M}>\mathrm{H}$ \\
\hline CERQ Önvád & $4,86(1,90)$ & $5,94(1,93)$ & $7,07(2,25)$ & $\begin{array}{c}\mathrm{F}(2)=28,86 \quad(<0,0001) \\
\eta^{2}=0,10\end{array}$ & $\mathrm{~V}<\mathrm{M}<\mathrm{H}$ \\
\hline CERQ Rumináció & $6,20(2,34)$ & $7,17(2,05)$ & $7,37(2,46)$ & $\begin{array}{c}\mathrm{F}(2)=12,35(<0,0001) \\
\eta^{2}=0,04\end{array}$ & $\mathrm{~V}<\mathrm{M}=\mathrm{H}$ \\
\hline CERQ Katasztrofizálás & $3,86(1,88)$ & $4,78(2,09)$ & $6,40(2,42)$ & $\begin{array}{c}\mathrm{F}(2)=28,32(<0,0001) \\
\eta^{2}=0,09\end{array}$ & $\mathrm{~V}<\mathrm{M}<\mathrm{H}$ \\
\hline CERQ Mások hibáztatása & $3,65(1,61)$ & $3,90(1,58)$ & $4,30(2,03)$ & $\begin{array}{c}\mathrm{F}(2)=3,04(=0,048) \\
\eta^{2}=0,01\end{array}$ & $\mathrm{~V}=\mathrm{M}=\mathrm{H}$ \\
\hline SAPS Standardok & $21,95(5,13)$ & $22,14(4,30)$ & $21,09(5,69)$ & $\begin{array}{c}\mathrm{F}(2)=0,97(=0,378) \\
\eta^{2}=0,004\end{array}$ & $\mathrm{~V}=\mathrm{M}=\mathrm{H}$ \\
\hline SAPS Diszkrepancia & $14,44(5,93)$ & $17,73(5,55)$ & $19,60(6,35)$ & $\begin{array}{c}\mathrm{F}(2)=23,66(<0,0001) \\
\eta^{2}=0,08\end{array}$ & $\mathrm{~V}<\mathrm{M}=\mathrm{H}$ \\
\hline BFI2 Extraverzió & $44,31(7,53)$ & $38,57(8,31)$ & $32,00(7,34)$ & $\begin{array}{c}\mathrm{F}(2)=49,21(<0,0001) \\
\eta^{2}=0,16\end{array}$ & $\mathrm{~V}>\mathrm{M}>\mathrm{H}$ \\
\hline BFI2 Barátságosság & $44,75(6,58)$ & $42,54(6,75)$ & $38,36(6,74)$ & $\begin{array}{c}\mathrm{F}(2)=16,26(<0,0001) \\
\eta^{2}=0,06\end{array}$ & $\mathrm{~V}>\mathrm{M}>\mathrm{H}$ \\
\hline BFI2 Lelkiismeretesség & $43,51(6,77)$ & $40,37(7,55)$ & $37,79(7,93)$ & $\begin{array}{c}\mathrm{F}(2)=14,48(<0,0001) \\
\eta^{2}=0,06\end{array}$ & $\mathrm{~V}>\mathrm{M}=\mathrm{H}$ \\
\hline BFI2 Érzelmi instabilitás & $31,60(7,06)$ & $38,20(7,82)$ & $46,10(7,77)$ & $\begin{array}{c}\mathrm{F}(2)=74,56(<0,0001) \\
\eta^{2}=0,22\end{array}$ & $\mathrm{~V}<\mathrm{M}<\mathrm{H}$ \\
\hline BFI2 Nyitottság & $47,10(7,42)$ & $45,04(7,95)$ & $42,12(8,58)$ & $\begin{array}{c}\mathrm{F}(2)=7,77 \quad(<0,0001) \\
\eta^{2}=0,03\end{array}$ & $\mathrm{~V}>\mathrm{M}>\mathrm{H}$ \\
\hline
\end{tabular}

Megjegyzés: *A jelzett csoportok közötti különbségek minimum $\mathrm{p}<0,05$ szinten szignifikánsak. $\eta^{2}=$ hatásméret mutató: 0,040-ig kis hatásméret; 0,060 és 0,110 között közepes hatásméret; 0,140-tôl erôs hatásméret. $\mathrm{V}=$ Virágzók, $\mathrm{M}$ = Mérsékelt mentális egészséggel bírók, $\mathrm{H}$ = Hervadók.

DASS = Depression Anxiety Stress Scales 21 itemes változat. CERQ = CERQ-short, Cognitive Emotion Regulation Questionnaire-short; Kognitív Érzelem-Reguláció Kérdőív rövid formája. SAPS = Short Almost Perfect Scale, Majdnem Tökéletes Skála rövidített változata. BFI2 = Big Five Inventory-2. 
között nincsen számottevő különbség. A tervezés, a helyzetek átértékelése és perspektívába helyezése esetében a virágzók érik el a legmagasabb pontszámokat. A maladaptív érzelemregulációs módoknál a virágzók a legalacsonyabb értékeket mutatják fel, kivéve a mások hibáztatásának stratégiáját, ahol az egyes szubjektív jóllét csoportok között nem mutatható ki különbség. Az egyes személyiségvonásokat tekintve a perfekcionizmus maladaptív vonulatával azonosítható Diszkrepancia esetében a legalacsonyabb értékeket a virágzók mutatják, a mérsékeltek és a hervadók között nincs különbség. A virágzók továbbá a legextravertáltabbak, a legbarátságosabbak, a leglelkiismeretesebbek, a legnyitottabbak és érzelmileg a legstabilabbak (9. táblázat).

\section{MEGBESZÉLÉS}

A Mentális Egészség Két-kontinuum Modelljére, mint teoretikus bázisra alapozva Keyes (2002a) az egyéni szubjektív jóllét szint felmérését célozta meg. Fontosnak tartotta, hogy a szubjektív jóllétet, azaz a pozitív mentális egészséget ne csupán egy osztatlan képzôdményként képezze le, hanem annak összetevôit is mérhetôvé tegye: így az érzelmi, a pszichológiai és a társas jóllét aspektusait külön-külön is összegezze.

Vizsgálatunkban a Mentális Egészség Két-kontinuum Modellje (Keyes, 2002a) alapján létrehozott Mentális Egészség Kontinuum Skála (Keyes és mtsai, 2008) pszichometriai mutatóit és faktorszerkezetét teszteltük hazai felnôtt egyetemista mintán. Ezzel egy valid, a szubjektív jóllét szintet megbízhatóan mérô önkitöltôs kérdôívet kívántunk bevezetni a magyar tesztállományba.

A kérdôív magyar változatán a tételek kereszttöltéseit is megengedô (ESEM) bifaktoros szerkezetet erôsítettünk meg. Mindez azt jelzi, hogy jelen van egy általános szubjektív jóllét faktor, amely mellett a három nagy szubjektív jóllét terület (érzelmi, pszichológiai és társas jóllét) mint specifikus faktorok körvonalazódnak. Azaz az eredeti, Keyes (2002a) által feltételezett struktúra (érzelmi, pszichológiai és társas jóllét) is érvényes interpretációval bír. Ugyanakkor ezek „kombinációja”, egy globális jóllét faktor is jelen van. Ráadásul az általános jóllét faktornak igen erôs a hatása, ami azt mutatja, hogy a három specifikus faktor az általános faktor hatásától erôsen függ. Az a variancia, amelyet tehát az egyes specifikus faktorok eredményeiben látunk, inkább a foofaktor - jelen esetben a globális jóllét mutató - hatása. A mérôeszköz ugyan nem egyfaktoros szerkezetú, mégis a három szubjektív jóllét faktort a globális szubjektív jóllét mutató jelentôsen befolyásolja. Ezt mindenképpen érdemes figyelembe venni a mérôeszközzel nyert eredmények késôbbi interpretációja során: az általános faktorhoz kapcsolódó értékek nyújtják a legmegbízhatóbb mérést. Az elmúlt évtizedben több külföldi vizsgálat is tesztelte az MHC-SF faktorstruktúráját, melyek kivétel nélkül - ahogy saját kutatásunk is - elvetették az egy- és a kétdimenziós faktorszerkezetet (pl. Machado és Bandeira, 2015). A nemzeti mintákon vagy az eredeti háromfaktoros (pl. Lamers és mtsai, 2011; Joshanloo, 2017) vagy a bifaktoros struktúrát (pl. Lamborn és mtsai, 2018; Rogoza és mtsai, 2018; Reinhardt és mtsai, 2020) igazolták. Utóbbit erôsítik jelen vizsgálati eredményeink is felnôtt mintán. Azt is megerósítettük vizsgálatunkban, hogy a kérdőív faktorszerkezetének vizsgálatakor az ESEM-alapú modellek 
jobb illeszkedést mutatnak, mint a CFA-alapúak, ami szintén egybevág az utóbbi évek több vizsgálatával (pl. De Bruin és Du Plessis, 2015; Rogoza és mtsai, 2018).

Lényeges megemlíteni a MEKS magyar változatának 4. tételét („valami fontossal járult hozzá a társadalomhoz”), amely a globális jóllét faktorra ugyan erôs faktortöltést mutat, azonban „eredeti” skálájához, a társas jóllét faktorhoz nem kapcsolódik. Ennek háttere lehet az eredeti kérdóívben („that you had something important to contribute to society”) és így a magyar fordításban is benne lévô „fontos” jelzô, amelyhez a saját társadalmi hasznosság jelentôsebb tetteit asszociálhatja a kitöltô, s így kevésbé érezheti önmagára jellemzónek. Ugyanakkor Keyes (1998) a tételhez tartozó jelenség leírásakor - bár az a személy társas/társadalmi közremúködésére (social contribution) vonatkozik - olyan mindennapi cselekedetekkel jellemzi ennek a területnek a tartalmát, mint mások segítése egy hasznos tanáccsal vagy a másik meghallgatásával. Ugyanakkor a kérdőív 4. tételében ez kevéssé fejezôdik ki, inkább a szociális értékesség „grandiózusabb” elemeit hívja elô, és nem a generativitás mindennapi, bárki által megélhetô formáit. Javaslatunk szerint a 4. tételt azzal lehetne egyértelmúbbé tenni, hogy zárójelben megemlítjük a mindennapi társas hozzájárulás egy-két formáját („valami fontossal járult hozzá a társadalomhoz, pl. segített másokon)”.

Fontos, hogy a mérôeszköz felnôtt egyetemista mintánkon a nemek tekintetében invariáns, azaz hasonló mérést biztosít mind a férfiak, mind a nôk körében, a tételeket mindkét nem képviselôi ugyanúgy értelmezik. Ez az eredmény is harmóniában van az eddigi nemzetközi kutatásokkal (pl. Petrillo és mtsai, 2014 vagy Sampaio de Carvalho és mtsai, 2016).

A MEKS kategoriális kiértékelése alapján a magyar egyetemista minta 30\%-a kiváló szubjektív jólléttel jellemezhetô (virágzók), kicsit több mint $60 \%$-uk közepes jóllétértékekkel bír (mérsékelt mentális egészségúek), és közel 8\%-uk alacsony szubjektív jóllétet jelez. Ezek az eredmények tendenciájukban hasonlóak a felnôtt (25 és 74 év közötti) amerikai (Keyes, Dhingra és Simoes, 2010) adatokhoz, ahol a virágzók közel 20\%-át, a mérsékeltek 64\%-át, a hervadók pedig 17\%-át tették ki a vizsgált populációnak. Az amerikai serdülők körében pedig $38 \%$ virágzót, $56 \%$ mérsékelt mentális egészséggel bírót és 6\% hervadót detektáltak (Keyes, 2006). A hazai egyetemista adatok az amerikai serdülőpopulációéhoz állnak közelebb.

Eredményeink szerint a magyar egyetemista férfiak és nôk átlagosan hasonló globális, érzelmi, pszichológiai és társas szubjektív jóllét szinttel jellemezhetôk. Mindez megegyezik a korábbi külföldi vizsgálatokban (pl. Robitschek és Keyes, 2009) kapott eredményekkel, ahol leggyakrabban nem mutatkozott nemi eltérés a pozitív mentális egészség mutatói tekintetében felnôtt mintában. Hasonlóképpen nem jelent meg eltérés a nemek között a pozitív mentális egészség dimenzionális felosztását tekintve sem, azaz közel ugyanannyi nô és férfi számít virágzónak, mérsékelt mentális egészségûnek és hervadónak (vö. pl. Khumalo, Temane és Wissing, 2012).

A MEKS-en alapuló eddigi vizsgálatokkal (pl. Keyes, 2002a; Keyes és mtsai, 2008) összhangban a mentális betegségtünetek jelenlétével szemben a virágzók a legvédettebbek, körükben nagyon alacsony depressziós, szorongásos és stressztünetszintet láthatunk. A hervadóknál a virágzókhoz képest 2-4-szer annyi neurotikus tünet jelenik meg, így ôk különösen veszélyeztetettek a hangulatzavarok kialakulása tekintetében. 
A hervadás leginkább a stagnálással, az üresség- és reménytelenségérzéssel írható le (Keyes, 2005a), hiszen az ebbe a csoportba tartozók nagyon kevés érzelmi, pszichológiai és társas jóllét komponenst élnek meg, azaz például alacsony autonómiaszintet, hatékonyságérzést, célállítási képességet - mind az egyéni, mind a szociális színtereken. Ezek a jellemzók a depresszió tekintetében rizikófaktorként jelennek meg. Ezt erôsíti meg Keyes, Dhingra és Simoes (2010) longitudinális vizsgálata, melyben a kezdetben „tisztán hervadók” (hervadók mentális betegségtünetek nélkül) hétszer nagyobb eséllyel kerültek a lelki betegség valamilyen diagnosztikai kategóriájába a kutatás tíz éve alatt, mint a mérsékeltek vagy a virágzók.

Eredményeink szerint a virágzók mozgósítják a legtöbb adaptív érzelemszabályozó mechanizmust: a stresszes, negatív érzelmeket kiváltó helyzeteket a leginkább ôk képesek pozitív módon átalakítani. Például azzal, hogy az adott helyzet megoldására valamilyen viselkedéses stratégiát dolgoznak ki, vagy azt pozitív jelentéssel ruházzák fel, vagy más, korábbi élményeikkel vetik össze azt. A virágzók továbbá kevés maladaptív érzelemszabályozó folyamatot alkalmaznak: a negatív helyzetekért kevéssé teszik magukat felelôssé, kevesebbet rágódnak terméketlenül azokon, valamint kevésbé nagyítják fel a szituációk negatív aspektusait. A hervadók az érzelemregulációs stratégiák alkalmazásában éppen a virágzó csoporttal ellentétes képet mutatnak.

A személyiségvonások tekintetében is a virágzók jellemezhetôk a legadaptívabb tulajdonságokkal. A virágzók úgy törekednek a személyes standardjaik betöltésére, hogy ahhoz kevés önmagukkal kapcsolatos elégedetlenség, önkritika társul. Másrészt a legjobb szociális képességekkel (extraverzió, barátságosság), felelósségérzettel (lelkiismeretesség), érzelmi kiegyensúlyozottsággal bírnak, és magas körükben az élményekre való nyitottság is. A hervadók mindennek az ellenkezőjét mutatják. Ezek az eredmények megerôsítik a korábbi vizsgálatokban kapottakat (pl. Lamers és mtsai, 2012), és a kérdôív megfelelő validitása mellett szólnak.

Mindennek gyakorlati konzekvenciái is vannak. Minél mélyebben megértjük ugyanis a virágzók erôsségeinek természetét és eredetét, annál aktívabban fel tudjuk azt használni a hervadó és/vagy a pszichésen beteg személyek kezelésében és az intervenciót célzó programok kialakításában (Keyes, 2007). A pszichés betegségek vizsgálata, a pszichés betegségtünetek felmérése során ezért érdemes volna a szubjektív jóllét tényezőit is szondázni. A mentális egészség fejlesztése a protektív faktorok vizsgálata, a szalutogenikus alapelvek (Keyes és Lopez, 2002; Provencher és Keyes, 2013) figyelembevétele nélkül ugyanis csak részlegesen lehetséges. A terápiás fókusznak a tünetcsökkentésen túl az optimális humán múködésre kell irányulnia. Utóbbi csakis a pozitív mentális egészség „tüneteinek” (Keyes, 2002a) azonosításával és fejlesztésével lehetséges. Az előbbihez kínál egy eszközt a Mentális Egészség Kontinuum Skála.

A MEKS konvergens és diszkrimináns validitásának adatai is megerôsítik a kérdôív alkalmasságát a szubjektív jóllét mérésére. A mentális betegségtünetekkel egyértelmú a globális jóllét mutató és az egyes alskálák (érzelmi, pszichológiai és társas jóllét) negatív kapcsolata, ahogyan a Big Five neuroticizmus dimenziójával, a maladaptív érzelemszabályozási módokkal és a maladaptív perfekcionista múködésmóddal való negatív összefüggés is kirajzolódott. A helyzetekhez hatékonyan illeszkedő, adaptív érzelemszabályozással és a Big Five extraverzió, barátságosság, lelkiismeretesség, valamint nyitottság dimenzióival a szubjektív jóllét mutatók - az elvártaknak megfele- 
lóen - pozitív kapcsolatot mutattak. Mindezek a korábbi eredményeket erôsítik (pl. Keyes és mtsai, 2008; Lamers és mtsai, 2012).

Vizsgálatunk több korláttal is bír: a keresztmetszeti elrendezés miatt ok-okozati viszonyokra nem következtethetünk adatainkból, és a tesztelt kérdôív faktorainak idôbeli stabilitását sem tudtuk emiatt vizsgálni. A kényelmi, nem reprezentatív mintavétel pedig korlátozza azt, hogy eredményeinket a teljes felnốtt populációra vonatkoztathassuk.

\section{KÖVETKEZTETÉSEK}

Eredményeink szerint a Mentális Egészség Kontinuum Skála magyar változata (MEKS) normatív - fiatal - felnoott populációban jól alkalmazható, pszichometriailag valid és megbízható méróeszköz. A skála képes a mentális egészség spektrumának felmérését árnyalni: rámutatva arra, hogy a mentális betegségtünetek mellett a kitöltố életében jelen vannak-e és milyen mintázatban a pszichés egészséget támogató szubjektív jóllét tényezôk.

\section{KÖSZÖNETNYILVÁNÍTÁS}

Reinhardt Melindát a Nemzeti Kutatási, Fejlesztési és Innovációs Hivatal (NKFIH) a PD 128332 számmal elnyert pályázat keretében támogatja. Horváth Zsoltot a Nemzeti Kutatási, Fejlesztési és Innovációs Hivatal (NKFIH) a 1157-8/2019-DT számú pályázattal támogatja. Kökönyei Gyöngyi a Nemzeti Kutatási, Fejlesztési és Innovációs Hivatal (NKFIH) az FK 128614 számú pályázatának keretében, illetve a Nemzeti Agykutatási Program (2017-1.2.1-NKP-2017-00002) keretében részesül támogatásban.

\section{IRODALOM}

Basson, M. J., \& Rothman, S. (2018). Flourishing: Positive emotion regulation strategies of pharmacy students. International Journal of Pharmacy Practice, 26(5), 458-464.

Cohen, J. (1992). A power primer. Psychological Bulletin, 112(1), 155-159.

Csikszentmihalyi, M., \& Csikszentmihalyi, I. S. (Eds), (1988). Optimal experience: Psychological studies of flow in consciousness. Cambridge University Press.

De Bruin, G. P., \& Du Plessis, G. A. (2015). Bifactor analysis of the Mental Health ContinuumShort Form (MHC-SF). Psychological Reports: Measures and Statistics, 116(2), 438-446. https:// dx.doi.org/10.2466/03.02.PR0.116k20w6

Diener, E. (1984). Subjective well-being. Psychological Bulletin, 95(3), 542-575.

Doré, I., O’Loughlin, J. L., Sabiston, C. M., \& Fournier, L. (2017). Psychometric evaluation of the Mental Health Continuum-Short Form in French Canadian young adults. The Canadian Journal of Psychiatry, 62(4), 286-294. https://dx.doi.org/10.1177/0706743716675855

Durayappah, A. (2011). The 3P Model. A General Theory of Subjective Well-Being. Journal of Happiness Studies, 12(4), 681-716. 
Fredrickson, B. L., \& Losada, M. F. (2005). Positive Affect and the Complex Dynamics of Human Flourishing. American Psychologist, 60(7), 678-686.

Garnefski, N., \& Kraaij, V. (2006). Cognitive emotion regulation questionnaire - development of a short 18-item version (CERQ-short). Personality and Individual Differences, 41, 1045-1053.

Garnefski, N., Kraaij, V., \& Spinhoven, P. (2001). Negative life events, cognitive emotion regulation and depression. Personality and Individual Differences, 30(8), 1311-1327.

Guo, C., Tomson, G., Guo, J., Li, X., Keller, C., \& Söderqvist, F. (2015). Psychometric evaluation of the Mental Health Continuum-Short Form (MHC-SF) in Chinese adolescents - a methodological study. Health and Quality of Life Outcomes, 13, 198. https://dx.doi.org/10.1186/ s12955-015-0394-2

Henry, J. D., \& Crawford, J. R. (2005). The short-form version of the Depression Anxiety Stress Scales (DASS-21): Construct validity and normative data in a large non-clinical sample. British Journal of Clinical Psychology, 44, 227-239.

John, O. P. (1989). Towards a taxonomy of personality descriptors. In D. M. Buss, \& N. Cantor (Eds), Personality psychology: Recent trends and emerging directions (pp. 261-271.). New York, NY: Springer. http://dx.doi.org/10.1007/978-1-4684-0634-4_20

Joshanloo, M. (2017). Factor structure and measurement invariance of the MHC-SF in the USA. European Journal of Psychological Assessment. https://dx.doi.org/10.1027/1015-5759/a000425

Joshanloo, M., \& Nosratabadi, M. (2009). Levels of Mental Health Continuum and Personality Traits. Social Indicators Research, 90(2), 211-224.

Joshanloo, M., Wissing, M. P., Khumalo, I. P., \& Lamers, S. M. A. (2013). Measurement invariance of the Mental Health Continuum-Short Form (MHC-SF) across three cultural groups. Personality and Individual Differences, 55(7), 755-759. http://dx.doi.org/10.1016/j. paid.2013.06.002

Keyes, C. L. M. (1998). Social Well-Being. Social Psychology Quarterly, 61(2), 121-140.

Keyes, C. L. M. (2002a). The Mental Health Continuum: From Languishing to Flourishing in Life. Journal of Health and Social Behavior, 43(2), 207-222. http://www.jstor.org/stable/3090197

Keyes, C. L. M. (2002b). Complete Mental Health: An Agenda for the 21st Century. In C. L. M. Keyes, \& J. Haidt, J. (Eds), Flourishing. Positive Psychology and the Life Well-lived (pp. 293-312.). Washington DC: American Psychological Association.

Keyes, C. L. M. (2005a). Mental Illness and/or Mental Health? Investigating Axioms of the Complete State Model of Health. Journal of Consulting and Clinical Psychology, 73(3), 539-548.

Keyes, C. L. M. (2005b). Chronic Physical Conditions and Aging: Is Mental Health a Potential Protective Factor? Ageing International, 30(1), 88-104.

Keyes, C. L. M. (2006). Mental Health in Adolescence: Is America's Youth Flourishing? American Journal of Orthopsychiatry, 76(3), 395-402.

Keyes, C. L. M. (2009a). The Nature and Importance of Positive Mental Health in America's Adolescents. In R. Gilman, E. S. Huebner, \& M. J. Furlong (Eds), Handbook of Positive Psychology in Schools (pp. 9-23.). New York: Routledge.

Keyes, C. L. M. (2009b). Brief description of the mental health continuum short form (MHC-SF). Manuscript. Atlanta.

Keyes, C. L. M. (2013). Promoting and Protecting Positive Mental Health: Early and Often Throughout the Lifespan. In C. L. M. Keyes (Ed), Mental Well-Being. International Contributions to the Study of Positive Mental health (pp. 3-28). New York: Springer.

Keyes, C. L. M., Dhingra, S. S., \& Simoes, E. J. (2010). Change in Level of Positive Mental Health as a Predictor of Future Risk of Mental Illness. American Journal of Public Health, 100(12), 2366-2371. 
Keyes, C. L. M., \& Haidt, J. (2002). Introduction: Human Flourishing - The Study of That Which Makes Life Worthwhile. In C. L. M. Keyes, \& J. Haidt (Eds), Flourishing. Positive Psychology and the Life Well-lived (pp. 3-12). Washington DC: American Psychological Association.

Keyes, C. L. M., \& Lopez, S. J. (2002). Toward a Science of Mental Health: Positive Directions in Diagnosis and Interventions. In C. R. Snyder, \& S. J. Lopez (Eds), Handbook of Positive Psychology (pp. 45-59). New York: Oxford University Press.

Keyes, C. L. M., \& Michalec, B. (2010). Viewing Mental Health from the Complete State Paradigm. In T. L. Scheid, \& T. N. Brown (Eds), A Handbook for the Study of Mental Health (pp. 125-134). New York: Cambridge University Press.

Keyes, C. L. M., Shmotkin, D., \& Ryff, C. D. (2002). Optimizing Well-Being: The Empirical Encounter of Two Traditions. Journal of Personality and Social Psychology, 82(6), 1007-1022.

Keyes, C. L. M., \& Waterman, M. B. (2003). Dimensions of Well-Being and Mental Health in Adulthood. In M. Bornstein, L. Davidson, C. L. M. Keyes, \& K. Moore (Eds), Well-Being: Positive Development Across the Life Course (pp. 477-497). New Jersey: Lawrence Erlbaum Associates, Publishers.

Keyes, C. L. M., Wissing, M., Potgieter, J. P., Temane, M., Kruger, A., \& Van Rooy, S. (2008). Evaluation of the Mental Health Continuum-Short Form (MHC-SF) in Setswana-Speaking South Africans. Clinical Psychology and Psychotherapy, 15(3), 181-192.

Khumalo, I. P., Temane, Q. M., \& Wissing, M. P. (2012). Socio-Demographic Variables, General Psychological Well-Being and the Mental Health Continuum in an African Context. Social Indicators Research, 105(3), 419-442.

Kiss, E. Cs. (2015). Protektív személyiségfaktorok. In Kiss, E. Cs., \& Sz. Makó, H. (szerk.), Gyász, krizis, trauma és a megküzdés lélektana (pp. 338-351). Pécs: Pro Pannónia Kiadói Alapítvány.

Lamborn, P., Cramer, K. M., \& Riderby, A. (2018). The structural validity and measurement invariance of the Mental Health Continuum-Short Form (MHC-SF) in a large Canadian sample. Journal of Well-Being Assessment, 2, 1-19. https:/ / dx.doi.org/10.1007/s41543-018-0007-z

Lamers, S. M. A., Westerhof, G. J., Bohlmeijer, E. T., Ten Klooster, P. M., \& Keyes, C. L. M. (2011). Evaluating the Psychometric Properties of the Mental Health Continuum-Short Form (MHC-SF). Journal of Clinical Psychology, 67(1), 99-110. http://dx.doi.org/10.1002/ jclp.20741

Lamers, S. M. A., Westerhof, G. J., Kovács, V., \& Bohlmeijer, E. T. (2012). Differential relationships in the association of the Big Five personality traits with positive mental health and psychopathology. Journal of Research in Personality, 46, 517-524. http://dx.doi.org/10.1016/j. jrp.2012.05.012

Lim, Y. (2014). Psychometric characteristics of the Korean Mental Health Continuum-Short Form in an adolescent sample. Journal of Psychoeducational Assessment, 32(4), 356-364. http:// dx.doi.org/10.1177/0734282913511431

Lovibond, S. H., \& Lovibond, P. F. (1995). Manual for the Depression Anxiety \& Stress Scales. 2nd Edition. Sydney: Psychology Foundation. http://www2.psy.unsw.edu.au/DASS/

Luijten, C. C., Kuppens, S., Van de Bongardt, D., \& Nieboer, A. N. (2019). Evaluating the psychometric properties of the Mental Health Continuum-Short Form (MHC-SF) in Dutch adolescents. Health and Quality of Life Outcomes, 17, 157. https://doi.org/10.1186/ s12955-019-1221-y

Lupano Perugini, M. L., De la Iglesia, G., Solano, A. J., \& Keyes, C. L. M. (2017). The Mental Health Continuum-Short Form in the Argentinian context: Confirmatory factor analysis and measurement invariance. Europe's Journal of Psychology, 13, 93-108. https://dx.doi. org/10.5964/ejop.v13i1.1163 
Machado, W. L., \& Bandeira, D. L. (2015). Positive mental health scale: Validation of the Mental Health Continuum-Short Form. Psico-USF, Branganca Paulista, 20, 259-274. http://dx.doi.o $\mathrm{rg} / 10.1590 / 1413-82712015200207$

Miklósi, M., Martos, T., Kocsis-Bogár, K., \& Perczel Forintos, D. (2011). A Kognitív ÉrzelemReguláció Kérdôív magyar változatának pszichometriai jellemzôi. Psychiatria Hungarica, 26(2), 102-111.

Muthén, L. K., \& Muthén, B. O. (1998-2017). Mplus User’s Guide. Eighth Edition. Los Angeles, CA: Muthén \& Muthén.

Nunnually, J. C. (1978). Psychometric Theory. 2nd edition. New York: McGraw-Hill.

Oláh A. (2012) (szerk.). A pozitív pszichológia világa. Akadémiai Kiadó: Budapest.

Oláh A., \& Kapitány-Fövény M. (2012). A pozitív pszichológia tíz éve. Magyar Pszichológiai Szemle, 67(1), 19-45.

Orpana, H., Vachon, J., Dykxhoorn, J., \& Jayaraman, G. (2017). Measuring positive mental health in Canada: construct validation of the Mental Health Continuum-Short Form. Health Promotion and Chronic Disease Prevention in Canada, 37, 123-130. https:/ / dx.doi.org/10.24095/ hpcdp.37.4.03

Peña Contreras, E. K., Lima Castro, S. E., Bueno Pacheco, G. A., Aguilar Sizer, M. E., Keyes, C. L. M., \& Arias Medina, W. P. (2017). Reliability and validity of the Mental Health Continuum (MHC-SF) in the Ecuadorian contexts. Ciencias Psicológicas, 11, 223-232. https:// dx.doi.org/10.22235/cp.v11i2.1499

Peterson, C., \& Seligman, M. E. P. (2004). Character Strength and Virtues. A Handbook and Classification. New York: Oxford University Press.

Petrillo, G., Capone, V., Caso, D., \& Keyes, C. L. M. (2014). The Mental Health Continuum-Short Form (MHC-SF) as a measure of well-being in the Italian context. Social Indicators Research, 121, 291-312. https:/ /dx.doi.org/10.1007/s11205-014-0629-3

Provencher, H. L., \& Keyes, C. L. M. (2013). Recovery: A Complete Mental Health Perspective. In C. L. M. Keyes (Ed), Mental Well-Being. International Contributions to the Study of Positive Mental health (pp. 277-297.). New York: Springer.

Reinhardt, M. (2014). Szubjektív jóllétünk érzelmi, pszichológiai és társas mozaikdarabkái - A mentális egészség kétkontinuum-modellje. In Fülöp, J., Mirnics, Zs., \& Vassányi, M. (Szerk.), Kapcsolatban - Istennel és emberrel (pp. 15-31.). Budapest: L’Harmattan Kiadó.

Reinhardt, M., Horváth, Zs., Morgan, A., \& Kökönyei, Gy. (2020). Well-being profiles in adolescence: Psychometric properties and Latent Profile Analysis of the Mental Health Continuum Model. Health and Quality of Life Outcomes, 18(95). https://doi.org/10.1186/ s12955-020-01332-0

Reinhardt, M., Rice, K. G., \& Tóth, L. (2019). Latent profiles of perfectionism, mental health and stress in American and Hungarian undergraduates. 40th STAR Conference of the Stress and Anxiety Research Society, Palma de Mallorca, Spanyolország, 2019. július 9-12.

Reinhardt M., Tóth L., \& Rice, K. G. (2019). Perfekcionista csoportok pozitív mentális egészsége - A perfekcionizmus, az érzelemszabályozás és a szubjektív jóllét mintázódása fiatal élsportolók körében. Magyar Pszichológiai Szemle, 74(3/3), 301-325. DOI: 10.1556/0016.2019.74.3.3

Rice, K. G., Richardson, C. M. E., \& Tueller, S. (2014). The Short Form of the Revised Almost Perfect Scale. Journal of Personality Assessment, 96(3), 368-379.

Robitschek, C., \& Keyes, C. L. M. (2009). Keyes's Model of Mental Health With Personal Growth Initiative as a Parsimonious Predictor. Journal of Counseling Psychology, 56(2), 321-329. https://dx.doi.org/10.1037/a0013954

Rogoza, R., Truong Thi, K. H., Różycka-Tran, J., Piotrowski, J., \& Żemojtel-Piotrowska, M. (2018). Psychometric properties of the MHC-SF: An integration of the existing measure- 
ment approaches. Journal of Clinical Psychology, 74(10), 1-17. https://dx.doi.org/10.1002/ jclp.22626

Ryff, C. D. (1989). Happiness Is Everything, or Is It? Explorations on the Meaning of Psychological Well-Being. Journal of Personality and Social Psychology, 57(6), 1069-1081.

Ryff, C. D., \& Singer, B. H. (2008). Know thyself and become what you are: A eudaimonic approach to psychological well-being. Journal of Happiness Studies, 9, 13-39.

Salama-Younes, M. (2011). Validation of the Mental Health Continuum Short Form and Subjective Vitality Scale with Egyptian Adolescent Athletes. In I. Brdar (Ed), The Human Pursuit of Well-Being. A Cultural Approach (pp. 221-234.). New York: Springer.

Sampaio de Carvalho, J., Salgado Pereira, N., Marques Pinto, A., \& Maroco, J. (2016). Psychometric properties of the Mental Health Continuum-Short Form: A study of Portoguese speaking children/youth. Journal of Child and Family Studies, 25, 2141-2154. http://dx.doi. org/10.1007/s10826-016-0396-7

Seligman, M. E. P. (2002). Authentic Happiness: Using the New Positive Psychology to Realize Your Potential for Lasting Fulfillment. New York: Free Press.

Seligman, M. E. P. (2008). Positive Health. Applied Psychology: An International Review, 57, 3-18.

Seligman, M. E. P. (2011). Flourish. A Visionary New Understanding of Happiness and Well-being. New York: Free Press.

Seligman, M. E. P., \& Csikszentmihalyi, M. (2000). Positive Psychology. An Introduction. American Psychologist, 55(1), 5-14.

Soto, C. J., \& John, O. P. (2017). The Next Big Five Inventory (BFI-2): Developing and Assessing a Hierarchical Model with 15 Facets to Enhance Bandwith, Fidelity, and Predictive Power. Journal of Personality and Social Psychology, 113(1), 117-143.

Suldo, S. M., \& Shaffer, E. J. (2008). Looking beyond psychopathology: The dual-factor model of mental health in youth. School Psychology Review, 37(1), 52-68.

Szabó, M. (2010). The short version of the Depression Anxiety Stress Scales (DASS-21): Factor structure in a young adolescent sample. Journal of Adolescence, 33(1), 1-8.

Vaillant, G. E. (2003). Mental Health. American Journal of Psychiatry, 160(8), 1373-1384.

Wang, X., Zhang, D., \& Wang, J. (2011). Dual-Factor Model of Mental Health: Surpass the Traditional Mental Health Model. Psychology, 2(8), 767-772.

Westerhof, G. J., \& Keyes, C. L. M. (2010). Mental Illness and Mental Health: The Two Continua Model Across the Lifespan. Journal of Adult Development, 17, 110-119.

World Health Organization (WHO) (2001). Declaration of Helsinki. Bulletin of the World Health Organization, 79(4), 373-374.

Yin, K. L., He, J. M., \& Fu, Y. F. (2013). Positive Mental Health: Measurement, Prevalence, and Correlates in a Chinese Cultural Context. In C. L. M. Keyes (Ed), Mental Well-Being. International Contributions to the Study of Positive Mental health (pp. 111-132). New York: Springer.

A cikk a Creative Commons Attribution 4.0 International License (https://creativecommons. org/licenses/by/4.0) feltételei szerint publikált Open Access közlemény, melynek szellemében a cikk bármilyen médiumban szabadon felhasználható, megosztható és újraközölhetô, feltéve, hogy az eredeti szerzó és a közlés helye, illetve a CC License linkje és az esetlegesen végrehajtott módosítások feltüntetésre kerülnek. (SID_1) 


\section{VALIDATION OF THE HUNGARIAN MENTAL HEALTH CONTINUUM-SHORT FORM}

\section{REINHARDT MELINDA - HORVÁTH ZSOLT - TÓTH LÁSZLÓ - KÖKÖNYEI GYÖNGYI}

Background and aims: The Two Continua Model of Mental Health summarizes the positive components of mental health. Our aim was to test the psychometric characteristics and the factor structure of the Hungarian version of the Mental Health Continuum-Short Form (MHC-SF), a measurement based on the Two Continua Model of Mental Health, among Hungarian university students.

Methods: 552 university students $(71.5 \%$ women, mean age $=22.09, S D=3,66)$ took part in the cross-sectional research. Respondents filled out the following questionnaires: Hungarian version of the MHC-SF; the Short Form of the Revised Almost Perfect Scale; the Depression Anxiety and Stress Scales (DASS-21), the short version of the Cognitive Emotion Regulation Questionnaire; the Big Five Invento$r y-2$.

Results: We strenghtened the bifactor structure of the Hungarian version of the MHC-SF in Exploratory Structural Equation Modeling (ESEM) framework, which allows the cross-loadings of the items. Beside the strong global subjective well-being factor specific (emotional, psychological, and social) well-being factors emerged. Measurement invariance across gender is also demonstrated. The reliabilty of the Hungarian MHC-SF is excellent ( $\omega=0.79-0.92)$, as well as its validity. As it was expected, indicators of positive mental health associated negatively with depressive, anxiety, and stress symptoms, furthermore self-critical and maladaptive perfectionism. In contrast, global and specific components of subjective well-being were in positive association with adaptive cognitive emotion regulation strategies and certain personality traits, like agreeableness, conscientiousness, emotional stability, and extraversion.

Conclusions: According to our results a valid questionnaire was introduced into the Hungarian test system, which can reliably measure global subjective well-being, as well as its specific components.

Keywords: subjective well-being, Mental Health Continuum-Short Form, validation, factor structure 


\section{FÜGGELÉK}

\section{MENTÁLIS EGÉSZSÉG KONTINUUM SKÁLA - RÖVID VÁLTOZAT (MHC-SF)}

Kérjük, válaszoljon a következô kérdésekre, amelyek arra vonatkoznak, hogy ÖN hogyan érezte magát az elmúlt egy hónapban. Jelölje be mindegyik sorban azt a négyzetet, amelyik a legjobban kifejezi, hogy milyen gyakran tapasztalta vagy érezte az alábbiakat:

\begin{tabular}{|c|c|c|c|c|c|c|}
\hline $\begin{array}{l}\text { Az elmúlt egy hó- } \\
\text { napban milyen } \\
\text { gyakran érezte azt, } \\
\text { hogy: }\end{array}$ & SOHA & $\begin{array}{l}\text { EGYSZER } \\
\text { VAGY } \\
\text { KÉTSZER }\end{array}$ & $\begin{array}{l}\text { KB. HETEN- } \\
\text { TE EGYSZER }\end{array}$ & $\begin{array}{l}\text { KB. HETENTE } \\
\text { KÉTSZER VAGY } \\
\text { HÁROMSZOR }\end{array}$ & $\begin{array}{l}\text { MAJDNEM } \\
\text { MINDEN NAP }\end{array}$ & $\begin{array}{l}\text { MINDEN- } \\
\text { NAP }\end{array}$ \\
\hline 1. boldog volt & & & & & & \\
\hline 2. megelégedett volt & & & & & & \\
\hline $\begin{array}{l}\text { 3. elégedett volt az } \\
\text { életével }\end{array}$ & & & & & & \\
\hline $\begin{array}{l}\text { 4. valami fontos- } \\
\text { sal járult hozzá a } \\
\text { társadalomhoz (pl. } \\
\text { segített másokon) }\end{array}$ & & & & & & \\
\hline $\begin{array}{l}\text { 5. tartozik egy } \\
\text { közösséghez (pl. } \\
\text { egy társadalmi } \\
\text { csoporthoz vagy a } \\
\text { lakókörnyezetében } \\
\text { élókhöz) }\end{array}$ & & & & & & \\
\hline $\begin{array}{l}\text { 6. a társadalmunk } \\
\text { minden ember } \\
\text { számára egy jó hely } \\
\text { vagy hogy egyre } \\
\text { jobb hellyé válik }\end{array}$ & & & & & & \\
\hline $\begin{array}{l}\text { 7. az emberek alap- } \\
\text { vetóen jók }\end{array}$ & & & & & & \\
\hline $\begin{array}{l}\text { 8. az a mód, ahogy } \\
\text { a társadalmunk mú- } \\
\text { ködik, megérthetố } \\
\text { (értelmezhetô) }\end{array}$ & & & & & & \\
\hline $\begin{array}{l}\text { 9. a személyisége } \\
\text { legtöbb részét szere- } \\
\text { ti, elfogadta }\end{array}$ & & & & & & \\
\hline $\begin{array}{l}\text { 10. a mindennapi } \\
\text { élettel kapcsolatos } \\
\text { kötelezettségeit jól } \\
\text { ellátta }\end{array}$ & & & & & & \\
\hline $\begin{array}{l}\text { 11. másokkal meleg } \\
\text { (szeretetteljes) és } \\
\text { bizalomteli kapcso- } \\
\text { latai voltak }\end{array}$ & & & & & & \\
\hline
\end{tabular}




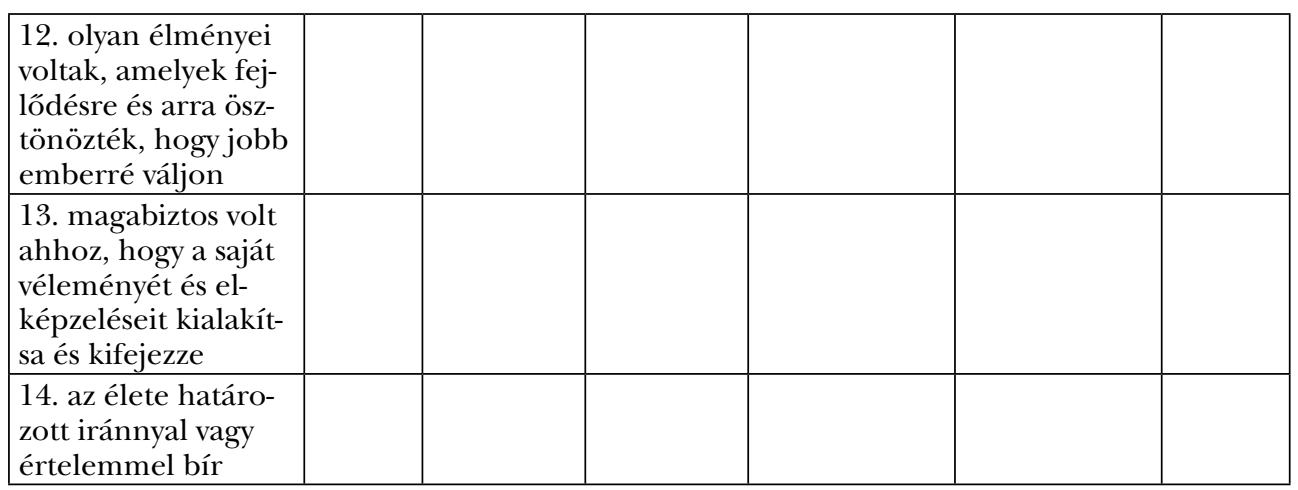

